\title{
The Role of Hydrogen Sulfide in Respiratory Diseases
}

\author{
Saadullah Khattak ${ }^{1,2,+}$, Qian-Qian Zhang ${ }^{1,+}$, Muhammad Sarfraz ${ }^{1,3}{ }^{\mathbb{D}}$, Pir Muhammad ${ }^{4}$, \\ Ebenezeri Erasto Ngowi $\left.{ }^{1,5}{ }^{(}\right)$, Nazeer Hussain Khan ${ }^{1,2}{ }^{\mathbb{D}}$, Saqib Rauf ${ }^{6}$, Yi-Zhen Wang ${ }^{1}$, Hui-Wen Qi $^{1}$, \\ Di Wang ${ }^{1}$, Attia Afzal ${ }^{1,3, * \mathbb{D}}$, Xin-Ying Ji ${ }^{1,7, *}$ and Dong-Dong $\mathrm{Wu}^{1,8, *}$
}

1 Henan International Joint Laboratory for Nuclear Protein Regulation, School of Basic Medical Sciences, Henan University, Kaifeng 475004, China; saadullah@henu.edu.cn (S.K.); 13323950805@163.com (Q.-Q.Z.); chiefpharm@gmail.com (M.S.); ebenezerngowi92@gmail.com (E.E.N.); Kakakhan3514@gmail.com (N.H.K.); yizhanwang713@163.com (Y.-Z.W.); qihuiwen0314@163.com (H.-W.Q.); w15858109412@163.com (D.W.)

2 School of Life Sciences, Henan University, Kaifeng 475004, China

3 Faculty of Pharmacy, The University of Lahore, Lahore 56400, Pakistan

4 Henan-Macquarie University Joint Centre for Biomedical Innovation, School of Life Sciences, Henan University, Kaifeng 475004, China; pir.muhammad786@gmil.com

5 Department of Biological Sciences, Faculty of Science, Dar es Salaam University College of Education, Dar es Salaam 2329, Tanzania

6 Department of Zoology, Islamia College University Peshawar, Peshawar, Khyber Pakhtunkhwa 25120, Pakistan; saqibrauf8@gmail.com

7 Kaifeng Key Laboratory of Infection and Biological Safety, School of Basic Medical Sciences, Henan University, Kaifeng 475004, China

8 School of Stomatology, Henan University, Kaifeng 475004, China

* Correspondence: attiapharm@gmail.com or attia.afzal@pharm.uol.edu.pk (A.A.); 10190096@vip.henu.edu.cn (X.-Y.J.); ddwubiomed2010@163.com (D.-D.W.); Tel.: +92-42-111865865 (A.A.); +86-371-23880585 (X.-Y.J.); +86-371-23880525 (D.-D.W.)

check for updates

Citation: Khattak, S.; Zhang, Q.-Q.; Sarfraz, M.; Muhammad, P.; Ngowi, E.E.; Khan, N.H.; Rauf, S.; Wang, Y.-Z.; Qi, H.-W.; Wang, D.; et al. The Role of Hydrogen Sulfide in Respiratory Diseases. Biomolecules 2021, 11, 682. https://doi.org/10.3390/biom11050682

Academic Editor: Alma Martelli

Received: 5 April 2021

Accepted: 27 April 2021

Published: 1 May 2021

Publisher's Note: MDPI stays neutral with regard to jurisdictional claims in published maps and institutional affiliations.

Copyright: (c) 2021 by the authors. Licensee MDPI, Basel, Switzerland. This article is an open access article distributed under the terms and conditions of the Creative Commons Attribution (CC BY) license (https:// creativecommons.org/licenses/by/ $4.0 /)$.
+ The authors contributed equally to this manuscript.

\begin{abstract}
Respiratory diseases are leading causes of death and disability around the globe, with a diverse range of health problems. Treatment of respiratory diseases and infections has been verified to be thought-provoking because of the increasing incidence and mortality rate. Hydrogen sulfide $\left(\mathrm{H}_{2} \mathrm{~S}\right)$ is one of the recognized gaseous transmitters involved in an extensive range of cellular functions, and physiological and pathological processes in a variety of diseases, including respiratory diseases. Recently, the therapeutic potential of $\mathrm{H}_{2} \mathrm{~S}$ for respiratory diseases has been widely investigated. $\mathrm{H}_{2} \mathrm{~S}$ plays a vital therapeutic role in obstructive respiratory disease, pulmonary fibrosis, emphysema, pancreatic inflammatory / respiratory lung injury, pulmonary inflammation, bronchial asthma and bronchiectasis. Although the therapeutic role of $\mathrm{H}_{2} \mathrm{~S}$ has been extensively studied in various respiratory diseases, a concrete literature review will have an extraordinary impact on future therapeutics. This review provides a comprehensive overview of the effective role of $\mathrm{H}_{2} \mathrm{~S}$ in respiratory diseases. Besides, we also summarized $\mathrm{H}_{2} \mathrm{~S}$ production in the lung and its metabolism processes in respiratory diseases.
\end{abstract}

Keywords: hydrogen sulfide; respiratory diseases; metabolism processes; signaling pathways

\section{Introduction}

Respiratory diseases are generally the most common disorders, mainly characterized by lesions located in the trachea, bronchi, lungs and chest. Typical clinical symptoms include cough, asthma and chest pain. Severe cases involve difficulty in breathing or even respiratory failure. Overall, respiratory diseases are physiologically categorized as obstructive or restrictive [1]. Obstructive diseases usually inhibit the flow rate into and out of the lungs, while the obstructive circumstances cause a reduction in the functional lung volume. Common respiratory diseases are pneumo-thorax, pulmonary bulla, emphysema, lung cancer, pulmonary heart disease, respiratory failure, pulmonary embolism, lung abscess, 
pneumonia, neonatal pneumonia, pediatric pneumonia, bronchitis, asthma, tuberculosis, pneumoconiosis and interstitial lung disease. Moreover, the respiratory tract infections can further be discriminated by the location (i.e., upper or lower tract infections) affected by bacterial or viral infections [2,3]. Over the past three decades, respiratory diseases' incidence has increased progressively in developed countries and attracted much attention. The World Health Organization (WHO) has defined chronic respiratory diseases as one of the chief diseases smiting the human world and has drawn much attention to their prevention, identification and treatment [4-6].

Hydrogen sulfide $\left(\mathrm{H}_{2} \mathrm{~S}\right)$ is found in a gaseous state, is soluble in water, and has a distinctive odor like rotten eggs. Formerly, $\mathrm{H}_{2} \mathrm{~S}$ was understood to be toxic due to its respiratory complex activities in mitochondria, resulting in cellular incapability to metabolize oxygen in an oxidative manner [7-9]. However, in recent years, there has been increasing evidence that $\mathrm{H}_{2} \mathrm{~S}$ plays an essential role in various physiological and pathological processes, such as inflammation [10-13], neuromodulation [14], injury repair [15] and hypertension [16]. Furthermore, Szabo et al. threw light on cancer, disclosing that cystathionine beta-synthase (CBS), one of the critical enzymes involved in the formation of $\mathrm{H}_{2} \mathrm{~S}$, is highly expressed in colorectal cancer cells in comparison with nearby adjacent normal mucosal margin cells [17]. On the other hand, both shRNA silencing and pharmacological treatment-mediated CBS inhibition can induce the suppression of the multiplication of cancerous cells in the colon both in vitro and in vivo.

Furthermore, both gene silencing of CBS and the pharmacological inhibition of CBS cause distinct energy conversion at the cell level in cancerous colon cells [17]. The ratio of $\mathrm{CBS}$ to $\mathrm{H}_{2} \mathrm{~S}$ plays a vital role in cancer progression, including in ovarian cancer [18] and breast cancer [19]. Otherwise, cystathionine $\gamma$-lyase (CSE) overexpression, another $\mathrm{H}_{2} \mathrm{~S}$-producing enzyme, has also been reported in melanoma [20]. Moreover, $\mathrm{H}_{2} \mathrm{~S}$ plays a vital role in cellular activities such as proliferation, angiogenesis, the function of the mitochondria and vascular relaxation, and is thought to be an essential factor in cancer biology [21-27]. $\mathrm{H}_{2} \mathrm{~S}$ is reported to induce both suppressive and inhibitory effects in human aorta SMC via the ERK/EGFR/MMP-2 and Akt/PTEN signaling pathways, and $\mathrm{H}_{2} \mathrm{~S}$ activates MAPK and caspase-3 to initiate apoptosis [28]. Meanwhile, sulfhydration of NF$\kappa \mathrm{B}$ by $\mathrm{H}_{2} \mathrm{~S}$ promotes anti-apoptotic activities [29]. It has been reported that phosphorylation of protein kinase Akt by $\mathrm{H}_{2} \mathrm{~S}$ can also induce anti-angiogenic properties [30-32]. The antioxidant capacity of $\mathrm{H}_{2} \mathrm{~S}$ has been investigated in specific animal experiments [33,34]. Nevertheless, the mechanisms by which $\mathrm{H}_{2} \mathrm{~S}$ is produced inside tumor cells and enhances cancer cell growth, are still being unraveled. Figure 1 highlights the essential roles of $\mathrm{H}_{2} \mathrm{~S}$ in the human body.

$\mathrm{H}_{2} \mathrm{~S}$ is closely related to respiratory activities and can affect the outcome of various respiratory diseases. For example, several studies have indicated that serum levels of $\mathrm{H}_{2} \mathrm{~S}$ in patients with chronic obstructive pulmonary disease (COPD) are low. This event is correlated with reduced chronic inflammation of the airway and vascular remodeling. Such activity shows the curative effects on pulmonary hypertension and asthma [35-38]. $\mathrm{H}_{2} \mathrm{~S}$ in the respiratory tract induces anti-apoptosis and anti-inflammatory effects and regulates vascular permeability. According to recent reports, patients with acute exacerbation of COPD have significantly low serum $\mathrm{H}_{2} \mathrm{~S}$, while serum levels of $\mathrm{H}_{2} \mathrm{~S}$ in smokers are much lower than in non-smokers [39].

Several pathways describe the damage of $\mathrm{H}_{2} \mathrm{~S}$ in respiratory diseases. However, some mechanisms are still not fully clarified. $\mathrm{H}_{2} \mathrm{~S}$ inhibits respiratory rhythm in neonates through the medulla [40]. $\mathrm{H}_{2} \mathrm{~S}$ can reduce other substances and is oxidized via circulating oxidants. $\mathrm{H}_{2} \mathrm{~S}$, together with $\mathrm{NO}, \mathrm{CO}$ and cyanide, are highly toxic, and micromolar concentrations can ultimately inhibit mitochondrial respiration [7]. $\mathrm{H}_{2} \mathrm{~S}$ is found in combination with sulfate and sulfur species. The compounds have variable forms ranging from persulfide and polysulfide to elemental sulfur. The compounds are reactive [41]. A species of sulfane-sulfur acts as a store of $\mathrm{H}_{2} \mathrm{~S}$, which maintains toxicity and allows $\mathrm{H}_{2} \mathrm{~S}$ to react with biological signals through sulfhydration [42,43]. Similarly, the sulfur compounds act 
through S-sulfhydration and are involved in most activities of $\mathrm{H}_{2} \mathrm{~S}$ [44]. Altered biosynthesis of $\mathrm{H}_{2} \mathrm{~S}$ is also linked with sulfate-sulfur levels based on pathophysiology, suggesting a close relationship.

The defective production of $\mathrm{H}_{2} \mathrm{~S}$ initiates several systemic disorders, and such a situation reveals the advance of effective pharmacological mediators that increase $\mathrm{H}_{2} \mathrm{~S}$ levels. $\mathrm{H}_{2} \mathrm{~S}$ modulation in pharmacy is a recent dynamic field that is well-reported and examined for specific significance [45-47]. Currently, a considerable number of natural and artificial compounds have been documented as potent $\mathrm{H}_{2} \mathrm{~S}$ donors [48], and many of them are in clinical trials for the treatment of cardiovascular disease (SG-1002 for heart failure) [48] and cancer (sulforaphane) [49]. In this review, the production and metabolism of $\mathrm{H}_{2} \mathrm{~S}$ in the lung are highlighted. Besides, the mechanisms and roles associated with the effects of $\mathrm{H}_{2} \mathrm{~S}$ in respiratory diseases are further explored.

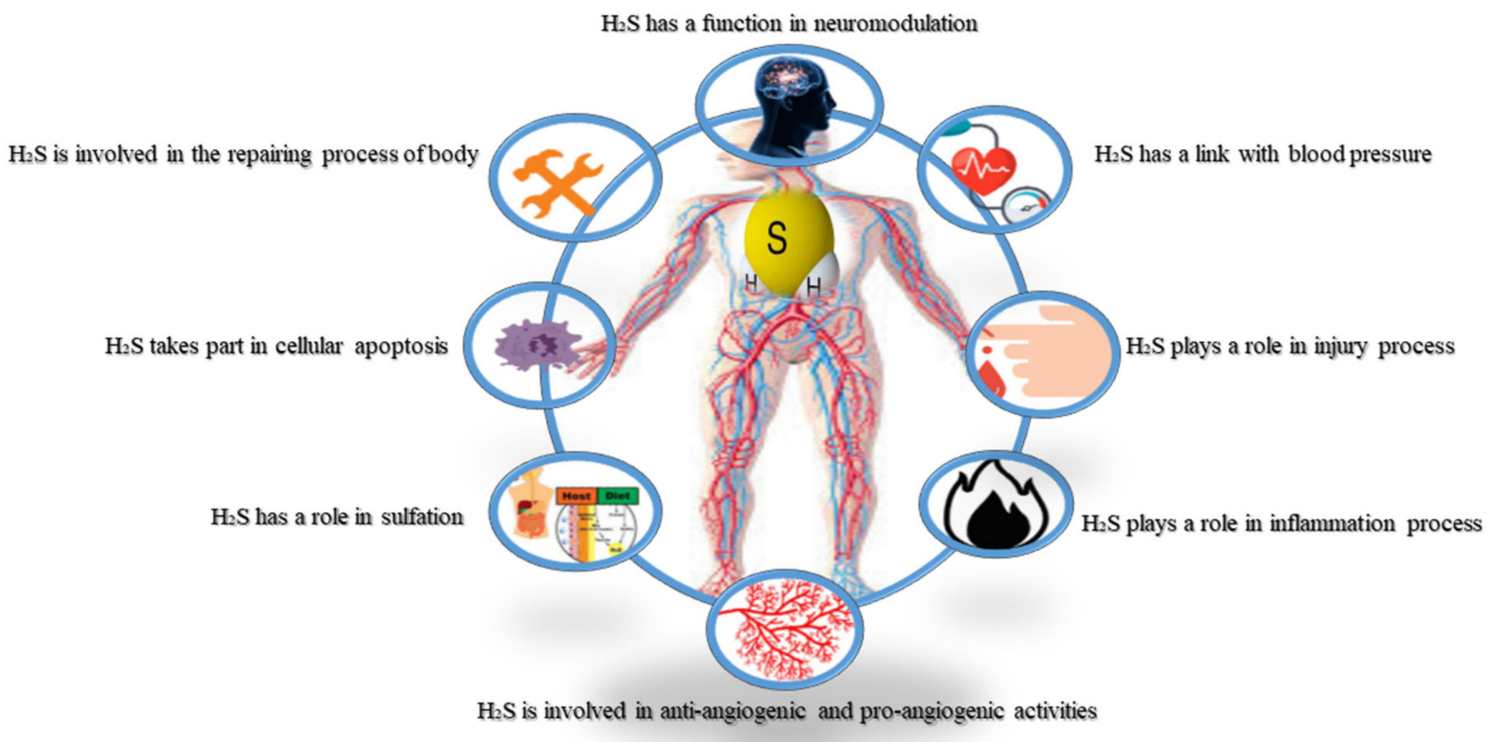

Figure 1. A schematic diagram showing the roles of $\mathrm{H}_{2} \mathrm{~S}$ in human physiology and pathology. $\mathrm{H}_{2} \mathrm{~S}$ is formed throughout the body and moderates signaling processes in various tissues, including neuromodulation, blood pressure, injury, inflammation, anti-angiogenesis, pro-angiogenesis and sulfhydration apoptosis repair processes of the human body $\left(\mathrm{H}_{2} \mathrm{~S}\right.$ : hydrogen sulfide).

\section{Regulation of $\mathrm{H}_{2} \mathrm{~S}$ and $\mathrm{H}_{2} \mathrm{~S}$-Mediated Sulfhydration in the Lung}

$\mathrm{H}_{2} \mathrm{~S}$ is produced via CSE, CBS and 3-mercaptopyruate transferase (3-MPST) in the lung, but various species or cell types show different expression levels of the three enzymes. Their catalytic activities are reinforced by the reducing enzymes, mainly sulfide-quinone reductase (SQR) and thiosulfate sulfide or thiocyanate (TST) as shown in Figure 2 [50].

The CSE is localized in the endothelium and smooth muscle, while 3-MPST is present in the mitochondria and cytoplasm [51]. Both human airway smooth muscle cells (SMCs) and human lung primary fibroblast MRC-5 cells express CSE and CBS. Immunohistochemical staining shows that CSE is present in the peripheral lung tissues of the airway and pulmonary vessels in rat lung, and mutually CSE and CBS are primarily expressed in pulmonary blood vessels, SMCs and endothelial cells, and airway SMCs in mouse lungs [52]. The catabolic process of $\mathrm{H}_{2} \mathrm{~S}$ in the mitochondria is thiosulfate production, which can be further converted to sulfide and then sulfate by rhodanese enzyme action. Besides, methylation of $\mathrm{H}_{2} \mathrm{~S}$ by thiol S-methyl transferase can produce dimethyl sulfide.

Most of the cellular responses mediated by $\mathrm{H}_{2} \mathrm{~S}$ initiate after sulfhydration and posttranslational modification of proteins [53]. Persulfides of $\mathrm{H}_{2} \mathrm{~S}$ can modify proteins containing the thiol group. The mechanism through which $\mathrm{H}_{2} \mathrm{~S}$ targets a particular thiol protein for S-sulfhydration is in its infancy. Some experimental data suggest that $\mathrm{H}_{2} \mathrm{~S}$ 
attacks thiol-containing proteins, which oxidise as thiolate ions for S-sulfhydration. For example, cysteine residues with a low $\mathrm{pKa}$ exist as thiolate anions in typical situations and hence are more definitely confronted by numerous oxidants and are susceptible to S-sulfhydration [54]. The acid-base idea might offer a latent clarification of the mechanism of protein S-sulfhydration. The S-sulfhydration of tissue/cell-specific proteins may occur due to the altered enzymatic activity of $\mathrm{H}_{2} \mathrm{~S}$-producing proteins.

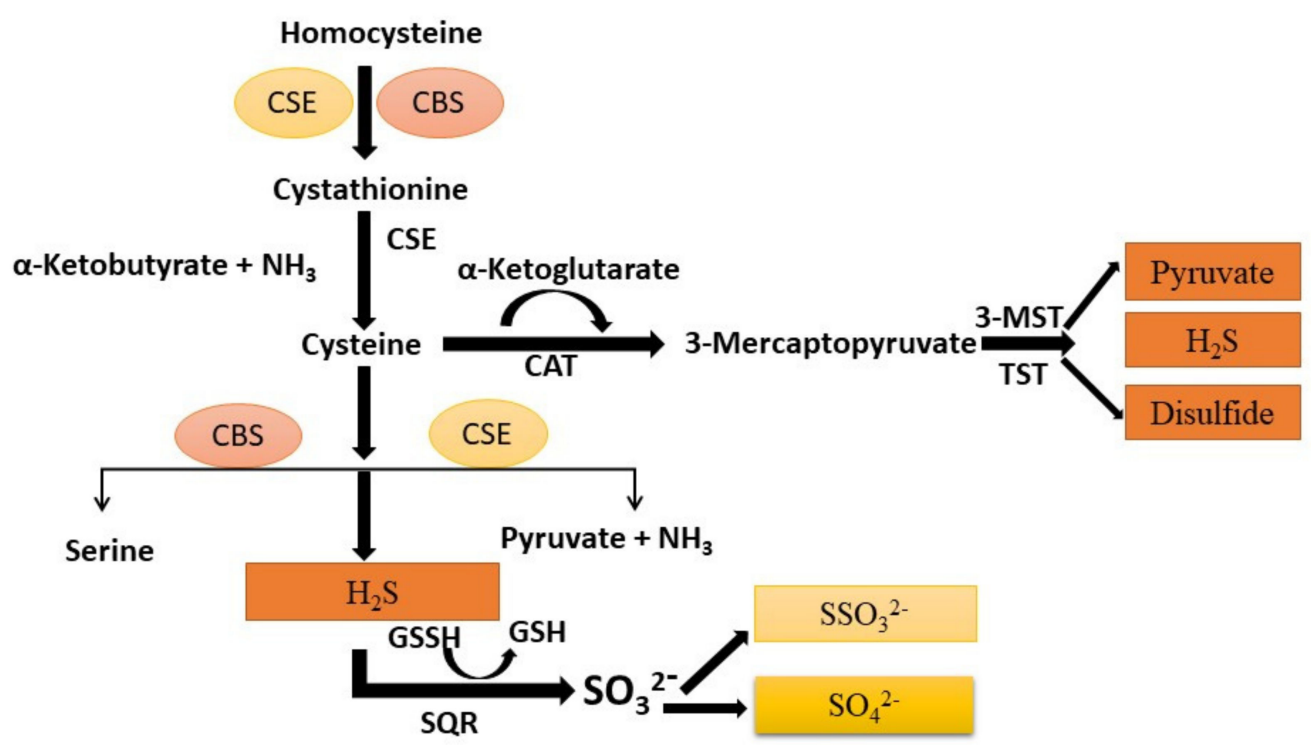

Figure 2. Illustration of vascular synthesis of $\mathrm{H}_{2} \mathrm{~S}$ formed by a catalytic process in several enzymes (CSE, CBS, and 3-MSPT) in the lung. Cysteine is generated from homocysteine through transculturation pathways intervened by CBS and CSE. $\mathrm{H}_{2} \mathrm{~S}$ forms from homocysteine and cysteine via CBS and CSE. 3-MSPT forms 3-MST-cysteine persulfide (MST-SSH) using mercapto pyruvate, which is formed from cysteine via CAT. $\mathrm{H}_{2} \mathrm{~S}$ is formed from MST-SSH via a non-enzymatic reaction. $\mathrm{H}_{2} \mathrm{~S}$ is oxidized via sulfide oxidation to form thiosulfate and sulfate. $\mathrm{H}_{2} \mathrm{~S}$ is produced from thiosulfate through a non-enzymatic reaction through reductants via the catalytic activity of thiosulfate sulfurtransferase or 3-MST. $\mathrm{H}_{2} \mathrm{~S}$ : hydrogen sulfide; SQR: sulfide-quinone reductase; CBS: cystathionine beta-synthase; CSE: cystathionine $\gamma$-lyase; 3-MPST: 3-mercaptopyravute sulfurtransferase; TST: thiosulfate sulfurtransferase; CAT: cysteine aminotransferase; GSSH: glutathione.

\section{The Role of $\mathrm{H}_{2} \mathrm{~S}$ in Respiratory Diseases}

\section{1. $\mathrm{H}_{2} \mathrm{~S}$ and Chronic Obstructive Pulmonary Diseases}

Pulmonary diseases such as emphysema, COPD and chronic bronchitis affect the respiratory tract's airflow. The hindrance is inferred in developing common chronic diseases such as respiratory failure, and pulmonary and heart diseases [55]. One of the key preventable causes of COPD is smoking. However, the mechanism of COPD is not entirely understood. Generally, COPD results from airway inflammation interacting with reactive oxygen species (ROS) [39]. Evidence shows that serum $\mathrm{H}_{2} \mathrm{~S}$ levels are significantly reduced in patients with COPD with acute exacerbations. Wang et al. show that $\mathrm{H}_{2} \mathrm{~S}$ acts efficiently to improve respiration and reduce histopathological variations, such as lung edema and permeability.

Oxidative stress, inflammation and airway remodeling also decrease via $\mathrm{H}_{2} \mathrm{~S}$ treatment [56]. $\mathrm{H}_{2} \mathrm{~S}$ exerts both pro- and anti-inflammatory effects. $\mathrm{H}_{2} \mathrm{~S}$ is anti-inflammatory and cyto-protective due to its ability to act as an antioxidant and a reducing agent, and its scavenging features [57]. NaHS, a donor of $\mathrm{H}_{2} \mathrm{~S}$, inhibits the in vitro production of intracellular oxidation and cellular damage induced by nitrates, hypochlorous acid and nitrous oxide (NO). It also inhibits the activity and expression of nicotinamide adenine dinucleotide phosphate (NADPH) and scavenges lipid peroxide [58]. Oleic acid induced lung injury in an animal model, while NaHS inoculation reduced lung injuries and plasma 
levels of interleukin (IL)-6 and IL-8, and the accumulation of inflammatory cells [59,60]. Moreover, in a murine model, the decrease in pro-inflammatory cytokine IL- $1 \beta$ and the rise of the anti-inflammatory cytokine IL-10 occurred after the administration of $\mathrm{H}_{2} \mathrm{~S}$ in smoke and burn-induced lung injury [61].

Furthermore, the elevation in the expression of CSE, CBS and $\mathrm{H}_{2} \mathrm{~S}$ levels in the pancreas, lung, liver, kidney and plasma of both mice and rats could cause acute inflammation [62]. The smoke of cigarettes is a primary etiological factor for the development of COPD in rat lungs. Treatment with NaHS can reduce lung inflammation and airway resistance caused by smoke [63]. A study shows that inhaled $\mathrm{H}_{2} \mathrm{~S}$ develops lung function and prevents bronchial hyper-reactivity by moderating mast cells and fibroblast initiation [64]. Higher levels of serum $\mathrm{H}_{2} \mathrm{~S}$ were positively correlated with severe COPD in stable COPD patients. Conversely, $\mathrm{H}_{2} \mathrm{~S}$ levels in the serum are decreased in exacerbated COPD in a steady disease state [37].

In contrast, $\mathrm{H}_{2} \mathrm{~S}$ levels in the sputum are higher in exacerbated COPD than in steadystate COPD, non-smokers and healthy subjects [65]. NaHS also protects against oxidative stress, airway inflammation, remodeling and an enhanced development rate of emphysema induced by tobacco smoke [39]. $\mathrm{H}_{2} \mathrm{~S}$ formation offers a new mechanism for suppressing airway smooth muscle (ASM) cell propagation and cytokine release. $\mathrm{H}_{2} \mathrm{~S}$ donors inhibit propagation and cytokine release in COPD ASM cells by inhibiting CBS and 3-MPST. However, COPD ASM cells' capacity to react to $\mathrm{H}_{2} \mathrm{~S}$ donors is not significant in smoker and non-smoker cells [66]. $\mathrm{H}_{2} \mathrm{~S}$ treatment inhibited elevated levels of transforming growth factor-beta 1 (TGF- $\beta 1$ ) and Smad in a cigarette smoke-induced COPD model via the inhibition of TGF- $\beta 1$ and Smad pathways.

It has been revealed that the serum levels of $\mathrm{H}_{2} \mathrm{~S}$ in smoker subjects are much lower than in non-smokers [39]. The endogenous $\mathrm{H}_{2} \mathrm{~S}$ is associated with the activity and severity of COPD [37]. Further studies showed that $\mathrm{H}_{2} \mathrm{~S}$ could protect macrophages from exposure to inflammation and oxidative stress, thereby enhancing macrophages' corticosteroid sensitivity [67]. Besides, low levels of $\mathrm{H}_{2} \mathrm{~S}$ in exhaled gases can be used to predict eosinophilia in patients [68]. Moreover, the sputum-to-serum ratio of $\mathrm{H}_{2} \mathrm{~S}$ can be used to predict obstructive neutrophilic inflammation and COPD progression [68]. The imbalance of $\mathrm{H}_{2} \mathrm{~S} / \mathrm{Hcy}$ may contribute to COPD pathogenesis combined with cardiovascular diseases, providing a new target for treatment [69]. The intrinsic enzymatic mechanism of $\mathrm{H}_{2} \mathrm{~S}$ expression in human airway SMCs has shown the potential for $\mathrm{H}_{2} \mathrm{~S}$ being exploited to treat obstructive pulmonary disease (Figure 3) [70].

\section{2. $\mathrm{H}_{2} \mathrm{~S}$ and Acute Lung Injury (ALI)}

ALI is considered to be a set of medical symptoms, such as hikes in the permeability of the epithelial and pulmonary vascular system, acute inflammation and microvascular damage, leading to acute respiratory failure and respiratory distress syndrome [65]. Many clinical diseases can cause ALI, such as pancreatic inflammatory lung injury, ventilator lung injury and burn lung injury [71,72].

$\mathrm{H}_{2} \mathrm{~S}$ reduces lung injury through numerous signaling pathways [73,74]. $\mathrm{H}_{2} \mathrm{~S}$ also assisted in reducing oxidative stress and inflammation to control LPS-induced acute ALI [75]. Exogenous $\mathrm{H}_{2} \mathrm{~S}$ prevented ALI by reducing mitochondrial lipid peroxidation and attenuating pro-inflammatory responses positively related to the $\mathrm{H}_{2} \mathrm{~S}$ dose to protect the cell structure in LPS-induced rat models [76]. $\mathrm{H}_{2} \mathrm{~S}$ inhalation prevents ALI by regulating p38 MAPK signal transduction and Nox-2 expression and synergistic inhibition of ROS formation [77]. Treating rats with $\mathrm{H}_{2} \mathrm{~S}$ reduced the transcription of iNOS mRNA, iNOS and nitric oxide (NO); inhibited the activation of NF- $\mathrm{kB}$ p65 and attenuated oxidative stress, thereby preventing ALI [78]. $\mathrm{H}_{2} \mathrm{~S}$ significantly reduces inflammation and pulmonary edema by regulating the TLR-4-Myd88-NF- $\mathrm{kB}$ pathway and AQP-1/AQP-5 expression [79]. Another study showed that thiosulfate inhibits NF-кB signaling in the pulmonary vascular endothelium to prevent ALI [80]. Simultaneously, the inhalation of $\mathrm{H}_{2} \mathrm{~S}$ triggers genes for anti-apoptosis and anti-inflammation via the regulation of activating transcription factor-3 
(ATF-3), demonstrating that ATF3 is noticeably involved in $\mathrm{H}_{2} \mathrm{~S}$-mediated protection [81]. Moreover, it has been revealed that dexamethasone can activate the PI3K pathway to improve the induction of $\mathrm{H}_{2} \mathrm{~S}$ in developing acute ALI by increasing the expression of claudin-5 [82]. Similarly, NaHS treatment inhibits the inflammation and oxidation reactions via activation of Nrf-2 cell signaling in preventing lung injury after explosive limb trauma [83]. Furthermore, it has been shown that $\mathrm{H}_{2} \mathrm{~S}$ also plays a role in preventing damage escalation in the alveoli and pulmonary hypertension (PHT) for lung injury induced by $\mathrm{O}_{2}$ [84]. While in another study, it was reported that intraperitoneal injection of $1 \mathrm{mg} / \mathrm{kg}$ NaHS improved the pulmonary levels of $\mathrm{H}_{2} \mathrm{~S}$ and oxidative stress-related signs (ROS, myeloperoxidase (MPO) and malondialdehyde (MDA)) in a time-dependent way. Liu et al. pointed out that $\mathrm{H}_{2} \mathrm{~S}$ attenuates oleic acid (OA)-induced lung injury by protective and upregulated endoplasmic reticulum proteins [85]. $\mathrm{H}_{2} \mathrm{~S}$ also protects against ALI by reducing the expression of MMP-2 and MMP-9 [86]. Some studies reported that $\mathrm{H}_{2} \mathrm{~S}$ induces a low metabolic status in anesthetized rats and prevents ventilator-induced lung injury by reducing lung inflammation unrelated to body temperature [87]. $\mathrm{H}_{2} \mathrm{~S}$ can also reduce lung $L / R$ injury pressure by reducing lung oxidation [15]. Alternatively, a study showed that an increment in the phosphorylation of myosin light chain (MLC) is protective against the toxicity of NaHS at the cellular level [33]. Meanwhile, an elevation in SMC properties, for instance, the expression of transgelin and motility, or a decrease in actomyosin improves cell survival after exposure to NaHS [87].

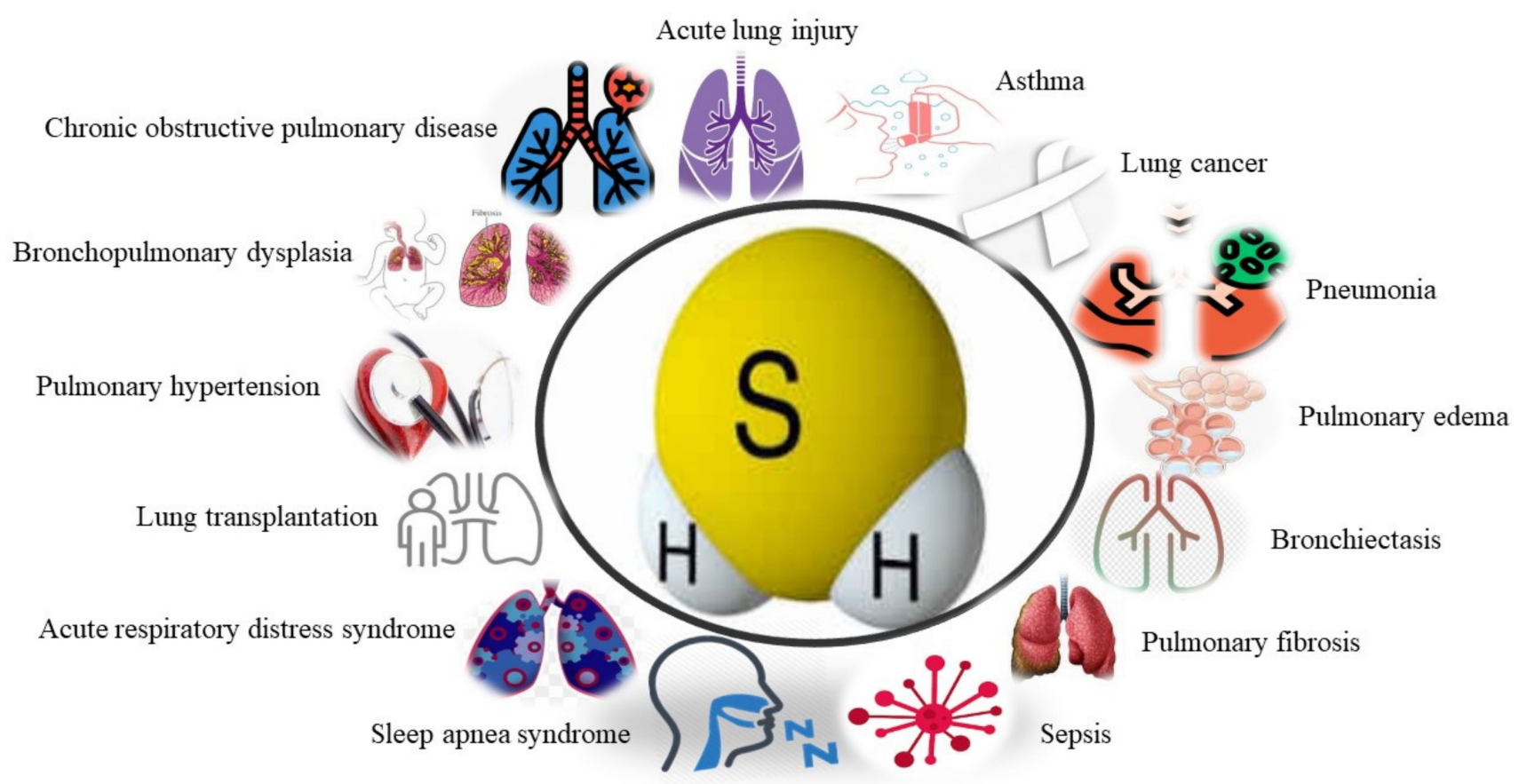

Figure 3. The roles of $\mathrm{H}_{2} \mathrm{~S}$ in human respiratory diseases, including COPD, ALI, asthma, lung cancer, pneumonia, pulmonary edema, bronchiectasis, pulmonary fibrosis, sepsis, SAS, ARDS, lung transplantation, pulmonary hypertension and bronchopulmonary dysplasia. COPD: chronic obstructive pulmonary disease; ALI: acute lung injury; ARDS: acute respiratory distress syndrome; SAS: sleep apnea syndrome; BPD: bronchopulmonary dysplasia.

\subsubsection{Pancreatic Inflammatory Lung Injury}

Pancreatic inflammatory lung injury encompasses a set of inflammatory diseases, such as acute pancreatitis. Severe acute pancreatitis is dangerous with poor prognosis, high mortality and early multiple organ failure, especially ALI. After acute pancreatitis, the $\mathrm{H}_{2} \mathrm{~S}$ synthase enzyme CSE in the pancreas induces morphological lung changes due to alveolar thickening and inflammatory cell infiltration [10]. Up to one third of all pancreatitis patients develop ALI or acute respiratory distress syndrome (ARDS), accounting for $60 \%$ of pancreatitis-associated deaths [88]. Bhatia et al. reported a good correlation between 
the level of $\mathrm{H}_{2} \mathrm{~S}$ and the severity of pancreatitis, and indicated that the pro-inflammatory effects of $\mathrm{H}_{2} \mathrm{~S}$ might be mediated by chemokines [89]. Tamizhselvi suggested that $\mathrm{H}_{2} \mathrm{~S}$ may exhibit potent vasodilation activity through the vascular smooth muscle KATP channel, thereby affecting acute pancreatitis and the associated lung injury [90]. Endogenous $\mathrm{H}_{2} \mathrm{~S}$ blocks sulfur mustard (SM)-induced oxidative damage through the Nrf-2 pathway [91]. Inhibition of CSE indicated anti-inflammatory outcomes in a murine model of pancreatitisinduced lung injury [10]. Bhatia et al. described that a high dose of $\mathrm{NaSH}(10 \mathrm{mg} / \mathrm{kg}$ I.P.) initiated lung inflammation and histological injury in mice, and this inflammation reverted to the baseline in $6 \mathrm{~h}$ post-injection, indicating that lethal consequences are due to high sulfide concentrations by the $\mathrm{H}_{2} \mathrm{~S}$ donor (NaHS), which were rapidly cleared [92]. The administration of NaHS or $\mathrm{H}_{2}$ S-releasing ACS15 [93] as a pre-treatment $(10-15 \mathrm{mg} / \mathrm{kg})$ decreased inflammation in pancreatitis-induced ALIs $[89,93]$. The study design influenced the role of NaHS. The high dose of $10 \mathrm{mg} / \mathrm{kg}$ of the $\mathrm{H}_{2} \mathrm{~S}$ donor NaHS caused ephemeral lung inflammation in healthy subjects. At the same time, its administration as a pretreatment induced anti-inflammatory effects in successive pancreatitis-induced ALI.

\subsubsection{Inhalation-Induced Lung Injury}

This refers to the degree of tracheal, bronchial and pulmonary parenchymal damage caused by various inhalation of harmful substances. Mild cases may only irritate cough and chest tightness; however, airway obstruction and pulmonary inflammation may also occur in severe cases. Even acute emphysema syndrome and multiple organ dysfunction syndromes (MODS) endanger the lives of patients. Burning is associated with a higher expression of CSE mRNA in the liver. Although $\mathrm{H}_{2} \mathrm{~S}$ administration reduces tissue damage and inflammation, $\mathrm{H}_{2} \mathrm{~S}$ donors exacerbate lung injuries caused by burns and smog inhalation in sheep $[94,95]$. On the other hand, treatment with $\mathrm{Na}_{2} \mathrm{~S}$ suppresses ALI caused by burns and smoke by attenuating iNOS expression, peroxynitrite formation, acute respiratory distress syndrome, nitro yield (lysine measurement), protein (oxidized protein carbonyl formation) and PARP-1 activity in vivo [94]. $\mathrm{H}_{2} \mathrm{~S}$ biosynthesis inhibitors such as AOAA and the mitochondria-targeted $\mathrm{H}_{2} \mathrm{~S}$ donor AP39 reduce intracellular and pulmonary plasma oxidative stress measured as MDA levels and cause organ infiltration into leukocytes (pulmonary MPO levels), pro-inflammatory and anti-inflammatory effects (circulating IL-6 and IL-10 levels), and liver and kidney dysfunction index (ALP and creatinine, respectively) [96]. Therapeutic administration of $\mathrm{H}_{2} \mathrm{~S}$ biosynthesis the inhibitor PAG in mice with lung injuries caused by burns reduces systemic inflammatory non-MPO activity [91].

\subsubsection{Ventilator-Induced Lung Injury (VILI)}

Although lung-protective ventilation strategies (LPVS) are regularly practiced for patients with ARDS, ventilator-induced lung injury (VILI) has received widespread attention as a common complication. $\mathrm{H}_{2} \mathrm{~S}$ relieves VILI by decreasing autophagy and endoplasmic reticulum stress in L2 cells and rats by decreasing PERK, PERK phosphorylation and nuclear expression ATF4 after treatment with NaHS [73]. The cyclin strain initiates nuclear NF-к $\beta$, MAPK, JNK, p65, p38, and ERK; whereas the ER stress inhibitor 4-PBA or $\mathrm{NaHS}$ suppress them. The $\mathrm{H}_{2} \mathrm{~S}$ donor NaHS and inhaled $\mathrm{H}_{2} \mathrm{~S}$ prevent ALI caused by ventilators [39]. $\mathrm{H}_{2} \mathrm{~S}$ decreases the migration of neutrophils and the release of cytokines, thus exerting anti-inflammatory effects [97]. $\mathrm{H}_{2} \mathrm{~S}$ limits lung injury due to ventilators by hindering ROS production via the PI3K/Akt signaling pathway [74]. Francis, R.C. et al. recommended systemic endovascular treatment with $\mathrm{Na} 2 \mathrm{~S}$, which prevents ventilator-induced lung injury and lung glutathione depletion by activating Nrf-2-dependent antioxidant gene transcription [98].

\section{3. $\mathrm{H}_{2} \mathrm{~S}$ and Asthma}

Asthma affects about 334 million individuals and has a high global death ratio [99]. Therefore, asthma is a leading international health, economic and social concern. However, 
asthma's pathogenesis includes allergies, chronic airway inflammation, responsiveness, airway neuromodulator disorders, genetic mechanisms, respiratory viral infections, neural signal transduction mechanisms and airway remodeling, and is not fully understood. The $\mathrm{H}_{2} \mathrm{~S}$ metabolism influences the physiology of the lung and the development of asthma. Condensed endogenous $\mathrm{H}_{2} \mathrm{~S}$ levels caused by the decline in $\mathrm{H}_{2} \mathrm{~S}$-producing enzymes may start an infective asthma infection aspect [52]. Alternatively, another study shows that a high dose ( $300 \mathrm{ppm}$ ) of $\mathrm{H}_{2} \mathrm{~S}$ diffuses into the bloodstream through the lung membrane and causes hypoxemia, vasodilation and vasoconstriction [100].

Further evidence reveals that $\mathrm{H}_{2} \mathrm{~S}$ stimulates the mitochondria to produce superoxide, which is converted to hydrogen peroxide $\left(\mathrm{H}_{2} \mathrm{O}_{2}\right)$ to mediate hypoxic vasoconstriction [51]. A previous experimental study in asthmatic patients also found that exogenous $\mathrm{H}_{2} \mathrm{~S}$ inhibits cell propagation and IL-8 release by attenuating the phosphorylation of ERK1/2 and p38 [101]. Clinical trials showed a strong association between serum $\mathrm{H}_{2} \mathrm{~S}$ levels and forced expiratory volume (FEV 1.0), and a negative correlation with sputum cell count and sputum neutrophil percentage in acute asthma patients [30]. Wang, P. et al. reported that oxidative stress and mitochondrial dysfunction are related to asthma's progress and development [52]. Similarly, antioxidants decrease mitochondrial dysfunction and oxidative stress in asthma [102]. A previous study revealed that endogenous $\mathrm{H}_{2} \mathrm{~S}$ reduces airway inflammation and renovation in rat asthma models [39].

Besides, asthmatic mice characterized by inflammation and ovalbumin (OVA) decreased $\mathrm{H}_{2} \mathrm{~S}$ production and CSE expression. Similarly, exogenous administration of NaHS reduced inflammation, and decreased airway infiltration by the neutrophils and eosinophils. Furthermore, NaHS reduced OVA, which initiates lung iNOS activation, restricting airway alterations. These facts indicate that $\mathrm{H}_{2} \mathrm{~S}$ formed from CSE acts as an anti-remodeling and anti-inflammatory mediator in asthma's pathogenicity [36]. In stable asthmatic patients or patients with acute exacerbation, $\mathrm{H}_{2} \mathrm{~S}$ level is lower in their serum. On the other hand, serum [52] or an exhaled air $\mathrm{H}_{2} \mathrm{~S}$ level [103] showed a positive relationship with forced expiratory volume and a negative association with neutrophil count [38]. The same results were recorded in small children having asthma [102].

\section{4. $\mathrm{H}_{2} \mathrm{~S}$ and Lung Cancer}

Lung cancer is one of the most prevalent malignities globally and is a prominent source of cancer-associated mortalities. Recent studies indicated that the expression of different $\mathrm{H}_{2} \mathrm{~S}$-producing enzymes in cancer cells of different tissue types is high, suggesting the gas's potential in developing the disease [83]. Szczesny et al. showed that severe mitochondrial DNA damage in lung cancer cells is linked to $\mathrm{H}_{2} \mathrm{~S}$ and that normal lung epithelial cells do not have elevated cell A549/DDP cells (compared with A549 cells) [104].

\section{5. $\mathrm{H}_{2} \mathrm{~S}$ and Pneumonia}

Pneumonia is an inflammation of the terminal respiratory tract, alveoli and interstitial lungs caused by microbes, physical and chemical factors, drug allergies and immune damage. Depending on the type of pathogen, it can be divided into fungal pneumonia, bacterial pneumonia, mycoplasma pneumonia and viral pneumonia. However, bacterial pneumonia is the most common kind of pneumonia and is a paramount public contagious infection. $\mathrm{H}_{2} \mathrm{~S}$ has pro-inflammatory effects in various inflammatory models [105-107]. In the inflammatory model, plasma $\mathrm{H}_{2} \mathrm{~S}$ levels, tissue $\mathrm{H}_{2} \mathrm{~S}$ synthesis activity and CSE expression increased. Some of the literature has stated the anti-inflammatory effects of $\mathrm{H}_{2} \mathrm{~S}$ treatments such as using s-diclofenac, ATB-429 and $\mathrm{H}_{2} \mathrm{~S}$ donors (NaHS, Lawson's reagent, $\mathrm{N}$-acetyl cysteine) in inflammation to produce anti-inflammatory activity $[58,95,107,108]$. Recent studies have also shown a biphasic dose-response effect of $\mathrm{H}_{2} \mathrm{~S}$ in inflammation [109].

$\mathrm{H}_{2} \mathrm{~S}$ has an anti-inflammatory effect in a dose-dependent manner on pulmonary inflammation [110]. It has been shown that supplementation with $\mathrm{H}_{2} \mathrm{~S}$ or inhibition of iNOS-induced elevation of the GSH/GSSG ratio is a possible mechanism for defending the airways from oxidative stress and inflammatory lung disease [111]. Prophylactic 
and therapeutic use of NaHS reduced total cell growth induced by ozone, containing macrophages and neutrophils. This type of treatment also reduces cytokine levels in broncho-alveolar lavage fluid, including TNF- $\alpha$, factor (CXC motif) ligand 1, IL-1 $\beta$ and IL-6 levels; inhibits them bronchially; attenuates the ozone-induced increase in total MDA in broncho-alveolar lavage fluid and reduces the ratio of condensed glutathione/oxidized glutathione in the lung. Besides, NaHS can block and reverse the phosphorylation of p38 MAPK and heat shock protein [103]. This shows that $\mathrm{H}_{2} \mathrm{~S}$ might have protective and therapeutic significance in treating airway diseases based on oxidative stress.

In 2013, Aslami et al. reported that NaHS might promote ATP synthesis and mitochondrial biogenesis by protecting oxidative phosphorylation to reduce organ damage in pulmonary sepsis caused by pneumococci [112]. Another study suggested that $\mathrm{H}_{2} \mathrm{~S}$ produced by Streptococcus pneumoniae causes hemolysis via the enzymatic activity of HapE (a protein similar to cysteine desulfurase) [113]. In respiratory syncytial virus (RSV), $\mathrm{H}_{2} \mathrm{~S}$ was found to have an overall inhibitory effect on paramyxoviruses (for example, human metapneumovirus (hMPV) and Nipah virus (NiV)) [114]. Pediatric cystic fibrosis can be chemically active, anoxic and highly condensed due to $\mathrm{H}_{2} \mathrm{~S}$ formation [115], and $\mathrm{H}_{2} \mathrm{~S}$ can upregulate cytokine and chemokine production, and aggravates NF- $\mathrm{kB}$ activation by participating in systemic inflammatory sepsis $[116,117]$. NaHS protects rat lungs from inflammatory responses through hemorrhagic shock, inhibiting oxidative stress, and Fas/FasL apoptotic signaling pathways [107]. In summary, different doses of NaHS and downregulation in lung inflammation were achieved through a reduction in pro-inflammatory chemokines and adhesion molecules.

\section{6. $\mathrm{H}_{2} \mathrm{~S}$ and Pulmonary Edema}

Pulmonary edema is caused by the accumulation of tissue fluid and the loss of the intrapulmonary tract. A considerable quantity of tissue fluid cannot be absorbed through the pulmonary lymphatic vessels and the pulmonary venous system quickly if it is extravagated from the pulmonary capillaries, and collects in the alveoli, interstitial lungs and small bronchi on the lungs $[118,119]$. Ventilation causes serious obstacles. The clinical manifestations include breathing difficulties, cyanosis, extreme dyspnea, paroxysmal coughing and excessive sweating with a large amount of white/pink foamy sputum and double-lung balanced wet voice coverage. Experiments have shown that inhibition of transepithelial $\mathrm{Na}+$ transportation gives a mechanism that improves edema development in $\mathrm{H}_{2} \mathrm{~S}$-exposed lungs [120-122]. NaHS decreases airway inflammation remodeling and tobacco smoke-induced oxidative stress, and enhances emphysema and developmental hypertension [39]. These protective outcomes are connected with improved phosphorylation of Akt and hindering of the downregulation of antioxidant molecules.

\section{7. $\mathrm{H}_{2} \mathrm{~S}$ and Bronchiectasis}

Bronchiectasis relates to the destruction of the bronchial wall muscles and elastic tissues affected by chronic suppurate inflammation and fibrosis of the bronchus and its adjacent lung tissues, resulting in bronchial deformation and continued expansion. Typical symptoms are chronic cough and repeated hemoptysis. There are two different perspectives on the effects of $\mathrm{H}_{2} \mathrm{~S}$ on bronchiectasis. Firstly, it leads to bronchodilation via regulation of the K-ATP channel and $\beta$-adrenergic receptors [123]. Secondly, the relaxation effect of $\mathrm{NaHS}$ is inactivated by $\mathrm{Ca} 2+$ influx and cholinergic receptor blockade [124]. Bronchiectasis is associated with increased $\mathrm{Cl}^{-}$and IкB phosphorylation. $\mathrm{H}_{2} \mathrm{~S}$ regulates $\mathrm{Cl}^{-}$levels and decreases phosphorylated I $\kappa \mathrm{B}$ expression, inhibiting the upregulation of pro-inflammatory cytokines in epithelial airway cells [125].

\section{8. $\mathrm{H}_{2} \mathrm{~S}$ and Pulmonary Fibrosis}

Pulmonary fibrosis is the most common form of interstitial lung illness. It involves a slow exchange of normal lung parenchyma and fibrotic tissues, leading to an irreparable reduction in oxygen diffusion ability. The causes of pulmonary fibrosis are diverse, and there 
are many triggers, e.g., chemicals, allergens, radiation and environmental particles [126]. The anti-fibrotic effect of $\mathrm{H}_{2} \mathrm{~S}$ on pulmonary fibrosis is that $\mathrm{H}_{2} \mathrm{~S}$ protects against oxidative stress and inflammation [127]. Studies indicate that the $\mathrm{H}_{2} \mathrm{~S}$ donor induces the nuclear buildup of Nrf-2 in lung tissues, thereby upregulating the expression of the Nrf-2-regulated antioxidant genes HO-1and Trx-1 in smoking rats $[91,126]$. Moreover, $\mathrm{H}_{2} \mathrm{~S}$ can decrease cigarette smoke-induced inflammation by preventing ERK1/2, JNK and p38 MAPK phosphorylation, and adversely regulating $\mathrm{NF}-\mathrm{K} \beta$ activation, thereby preventing pulmonary fibrosis in smoking rats (Figure 4) [128]. Wang et al. also have shown that the anti-fibrotic effect of $\mathrm{H}_{2} \mathrm{~S}$ relates to the inhibition of the TGF $\beta$ /Smad pathway [129]. In contrast, a high concentration of $\mathrm{H}_{2} \mathrm{~S}(50-500 \mathrm{ppm}$ ) may produce occlusive bronchiolitis and pulmonary edema, leading to chronic inflammation and pulmonary fibrosis [130].

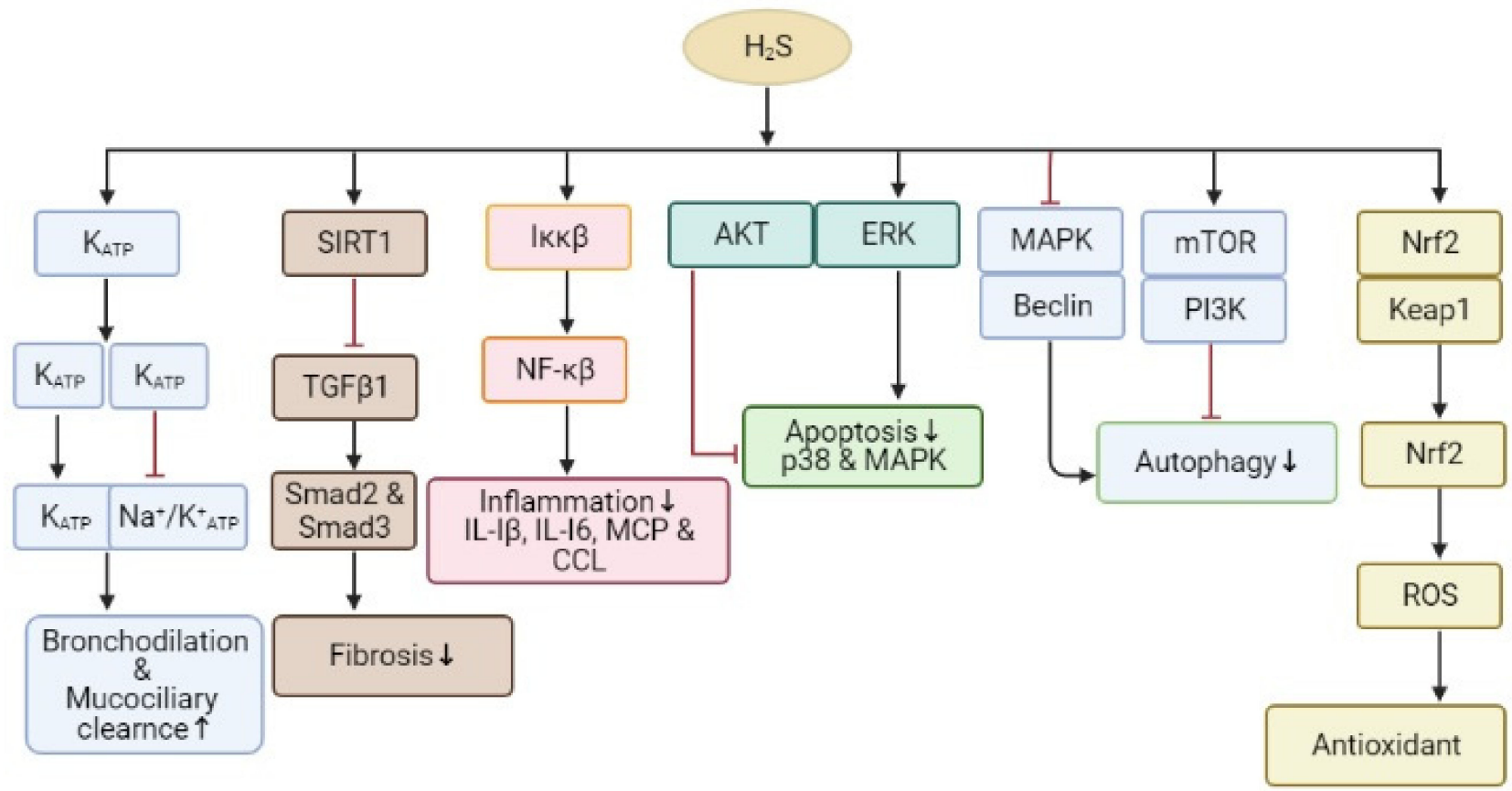

Figure 4. The signaling pathways underlying $\mathrm{H}_{2} \mathrm{~S}$ regulation of inflammation, fibrosis, apoptosis, autophagy, antioxidant activity and bronchodilation. $\mathrm{H}_{2} \mathrm{~S}$ has an anti-inflammatory outcome with diverse biological results, directly and indirectly decreasing activities such as Nrf2 activation. Abbreviations: ROS: reactive oxygen species, NF-к $\beta$ : nuclear factor-kappa B; Nrf2: nuclear factor erythroid-2 related factor 2; HO-1: heme oxygenase-1; PI3K: phosphoinositide 3-kinase; AMPK: AMPactivated protein kinase; ERK: extracellular signal-regulated kinase; TNF- $\alpha$ : tumor necrosis factor; TGF- $\beta 1$ : transforming growth factor-beta 1; Keap1: Kelch-like-ECH-associated protein; IL: interleukin; IKK: IrB kinase.

\section{9. $\mathrm{H}_{2} \mathrm{~S}$ and Sepsis}

The incidence of sepsis is high, with more than 19 million severe sepsis cases occurring worldwide each year [131]. The underlying pathogenesis of sepsis remains unclear. It involves complex systemic inflammatory network effects, genetic polymorphisms, immune dysfunction and coagulopathy. $\mathrm{H}_{2} \mathrm{~S}$ activates the selective transient receptor potential vanilloid 1 (TRPV1) by enhancing the upregulation of COX-2 and PGEM, coordinating with the neurogenic inflammatory response. The overproduction of substance $P$ initiates a neuro-inflammatory process, namely ERK-NF-K $\beta$. ERK-NF- $K B$ is activated in a TRPV1dependent manner and significantly increases sepsis severity $[90,132] . \mathrm{H}_{2} \mathrm{~S}$ upregulates substance $\mathrm{P}$ by activating the substance $\mathrm{P}$ receptor to coordinate the inflammatory response, leading to lung inflammation and sepsis damage [133]. The failure of exogenous $\mathrm{H}_{2} \mathrm{~S}$ to prevent neutrophil migration caused a noteworthy decrease in mortality in a mouse model of ALI [90]. 


\subsection{0. $\mathrm{H}_{2} \mathrm{~S}$ and Lung Transplantation}

Among the lung transplantation diseases, COPD, idiopathic pulmonary fibrosis (IPF), cystic fibrosis, sap-1 antitrypsin deficiency and idiopathic pulmonary hypertension are the main predisposing factors. In clinical practice, lung transplantation is a surgical process, either as single lung transplantation, double lung transplantation, cardiopulmonary transplantation or live lung transplantation. Lung ischemia reperfusion (IR) injury is still the main reason for the early mortality of lung transplantation [134]. A preliminary study reported an experimental model for the application of $\mathrm{H}_{2} \mathrm{~S}$ inhalation after longterm ischemia. In this study, lungs pretreated with inhaled $\mathrm{H}_{2} \mathrm{~S}$ showed an improvement in graft function during reperfusion, indicating the therapeutic use of $\mathrm{H}_{2} \mathrm{~S}$ in the lung transplantation experimental model [135].

Similarly, pretreatment in a rat model with intra-peritoneal NaHS administration significantly improved pulmonary function, and decreased lipid peroxidation and MPO activity after lung transplantation. Besides, NaHS inhibits interleukin $1 \beta$ but increases interleukin 10 levels in graft lung tissues [136]. The rat model of diabetes mellitus suffering from ischemia reperfusion after lung transplantation decreased ischemi-reperfusion-related oxidative stress after treatment with a slow-releasing $\mathrm{H}_{2} \mathrm{~S}$, GYY4137 [134]. $\mathrm{H}_{2} \mathrm{~S}$ attenuated lung IR injury in Type 2 diabetic disorder through the initiation of lung SIRT1 signaling, which upregulates the Nrf2/HO-1 and eNOS-mediated antioxidant signaling pathways, therefore decreasing cell apoptosis and inflammation, and finally having a protective lung function.

\subsection{1. $\mathrm{H}_{2} \mathrm{~S}$ and Pulmonary Hypertension}

Pulmonary hypertension $(\mathrm{PH})$ is a chronic infection described by central pulmonary vascular pressure and may be caused by various disease processes. Regardless of the cause, $\mathrm{PH}$ is a progressive disease. New therapeutic drugs are often decompensated in the advanced stage and usually have a poor prognosis [137]. A decrease in the endogenous $\mathrm{H}_{2} \mathrm{~S}$ pathway in hypertension and pulmonary vascular structural remodeling caused a high pulmonary blood flow in mice [138]. $\mathrm{H}_{2} \mathrm{~S}$ inhibits arterial elastin expression in its extracellular matrix [35]. In a hypoxic rat model with pulmonary artery smooth muscle cells, $\mathrm{H}_{2} \mathrm{~S}$ effectively inhibited a hypoxia-induced increase in cell proliferation, migration and oxidative stress in PASMCs [139]. $\mathrm{H}_{2} \mathrm{~S}$ can enhance total antioxidant capacity by attenuating the GSSG content levels in hypoxia-induced pulmonary hypertensive rats lung tissue and exert an antioxidation effect [140]. Endogenous $\mathrm{H}_{2} \mathrm{~S}$ is downregulated in $\mathrm{PH}$, and pulmonary vascular remodeling is influenced through high pulmonary blood flow. $\mathrm{NaHS}$ and endogenous $\mathrm{H}_{2} \mathrm{~S}$ can also prevent elevated pulmonary hypertension, pulmonary vascular remodeling and high pulmonary blood flow due to chronic hypoxia [39].

\subsection{2. $\mathrm{H}_{2} \mathrm{~S}$ and Sleep Apnea Syndrome (SAS)}

According to the American Sleeping Society, SAS refers to the complete collapse of the upper airway, with the disappearance of airflow but the presence of respiratory motion, characterized by the airflow disappearing for more than $10 \mathrm{~s}$, with significant chest breathing or esophageal pressure fluctuations. Central sleep apnea syndrome (CSAS) is characterized by the complete disappearance of airflow and respiratory movements that disappear for more than $10 \mathrm{~s}$; the airway is not entirely blocked when ventilation is insufficient and airflow is weakened. Arousal and hypoxemia $\left(>3 \% \mathrm{SaO}_{2}\right)$ occur frequently. Mice deficient in HO-2 produce the gaseous molecule carbon monoxide (CO) and exhibit sleep apnea, categorized through high apnea and hypopnea indices [141]. The glomus cells in the primary sensory organ, the carotid body $(\mathrm{CB})$, are responsible for monitoring arterial blood $\mathrm{O}_{2}, \mathrm{CO}_{2}$ and $\mathrm{pH}$ levels. In rodents, obstruction of $\mathrm{H}_{2} \mathrm{~S}$ production through CSE and pharmacologic or genetic methods inhibits carotid body activity, and hypertension is induced through intermittent hypoxia. During hypoxia, ROS triggers carbon monoxide synthesis by HO-2 and inhibits the synthesis of $\mathrm{H}_{2} \mathrm{~S}$ by inhibiting CSE [142]. During hypoxia, as compared with normoxia, $\mathrm{HO}-2$ produces less $\mathrm{CO}$, subsequently augmenting 
the production of $\mathrm{H}_{2} \mathrm{~S}$, which motivates $\mathrm{CB}$ activity, resulting in increased respiration rate, heart rate and blood pressure. It has been reported that a decrease in $\mathrm{CO}$ and an increase in $\mathrm{CB}$ in $\mathrm{H}_{2} \mathrm{~S}$ generation led to sleep apnea in HO-2 knockout mice and impulsively hypertensive mice [141].

\subsection{3. $\mathrm{H}_{2} \mathrm{~S}$ and Acute Respiratory Distress Syndrome}

ARDS is a clinical disorder categorized by obstinate hypoxemia. It has attracted much attention due to its high mortality rate. The causes of acute respiratory distress syndrome are numerous, and the pathogenesis of ARDS caused by different reasons is also different. Oxidative stress, including the formation of superoxide $(\mathrm{O} 2 \bullet-)$, might play a vital role in the pathogenesis of ARDS. $\mathrm{H}_{2} \mathrm{~S}$ gas intoxication develops ARDS, demanding a high rate of percussive ventilation [143]. In addition to direct vasoconstriction, O2•- also reacts with $\mathrm{NO}$ to form peroxynitrite and other reactive nitrogen, effectively reducing $\mathrm{NO}$ bioavailability. $\mathrm{H}_{2} \mathrm{~S}$ inhibited $\mathrm{O} 2 \bullet-$ formation in porcine aorta-derived endothelial cells, and the adenylate cyclase-PKA pathway upregulated NADPH oxidase. $\mathrm{H}_{2} \mathrm{~S}$-donating sildenafil may effectively treat ARDS through increasing cAMP and preventing Type 5 phosphodiesterase activity [144].

\subsection{4. $\mathrm{H}_{2} \mathrm{~S}$ and Bronchopulmonary Dysplasia (BPD)}

BPD is a chronic lung infection that causes persistent respiratory distress. It is caused mainly by hyperoxia, mechanical ventilation and inflammation, and categorized through impaired alveolar growth and complex pulmonary hypertension (PHT) [84,145]. It exhibits substantial streaks and overexpansion characteristics in X-rays. $\mathrm{H}_{2} \mathrm{~S}$ showed a protective effect in a BPD rodent model through HO-1 [145]. GYY4137 preserved and restored mitochondrial function in alveolar epithelial cells and normal alveolar development in mice pups exposed to hyperoxia for 2 weeks after birth [84]. The effect of NaHS on the migration of alveolar Type II (ATII) cells was reduced by glibenclamide, implicating ion channels, and was accompanied by Akt activation, suggesting two probable mechanisms of $\mathrm{H}_{2} \mathrm{~S}$ action. Such work triggers more study of $\mathrm{H}_{2} \mathrm{~S}$ as an applicant interventional approach to bind the prevented alveolarization linked with BPD [146].

\section{4. $\mathrm{H}_{2} \mathrm{~S}$ in the Physiopathology of Airways}

$\mathrm{H}_{2} \mathrm{~S}$ regulates some airways' physiological processes, both in human and animal models, as summarized in Table 1. Disorders of the endogenous formation of $\mathrm{H}_{2} \mathrm{~S}$ are connected to pathological procedures and the development of numerous ailments, including hypertension, hypoxic pulmonary hypertension and myocardial injury $[35,147,148]$. $\mathrm{H}_{2} \mathrm{~S}$ mediates smooth muscle relaxation via high airway activity inhibition caused by smoke from cigarettes, ozone and ovum albumin. On the other hand, $\mathrm{H}_{2} \mathrm{~S}$ intensifies the said effects if inhibited [149]. This relaxation was due to endogenous $\mathrm{H}_{2} \mathrm{~S}$ production in porcine airways [150]. The precursors of $\mathrm{H}_{2} \mathrm{~S}$, such as L-cysteine, also produce relaxation in the airway, but an inhibitor of CBS, amino oxy-acetic acid, inhibits the relaxation activity. The relaxation of smooth muscle also involves the inhibition of $\mathrm{H}_{2} \mathrm{~S}$, which relaxes the smooth muscle inhibition of Ca2+ release via InsP3 receptors [151] and the K+ channel [150]. Tracheal smooth muscle cells of mice showed hyper-movement through the potassium channels by stimulating the large-conductance calcium-activated potassium channel (BKCa) after treatment with NaHS. Such action causes the inhibition of Ca2+ influx and hyper-polarization of cells [152]. In contrast, relaxation was caused by $\mathrm{H}_{2} \mathrm{~S}$ via opening the KATP channels in smooth muscle cells of human airways [70]. The inhibition of phosphorylation of extracellular p38MAPK and ERK1/2 by $\mathrm{H}_{2} \mathrm{~S}$ has an inverse effect on the multiplication of smooth muscle cells and interleukin-8 release induced in fetal calf serum [101]. $\mathrm{H}_{2} \mathrm{~S}$ also regulates the physiological function of vessels, thus acting as a vaso-relaxant agent [153]. $\mathrm{H}_{2} \mathrm{~S}$ also enhances $\mathrm{NO}$ signaling in vessels [45] and vasodilatation of the pulmonary artery in rat [154]. 


\section{5. $\mathrm{H}_{2} \mathrm{~S}$ in Pulmonary Inflammation}

Endogenous and exogenous $\mathrm{H}_{2} \mathrm{~S}$ acts in the respiratory system via controlling mucolytic function. $\mathrm{H}_{2} \mathrm{~S}$ can make the mucus less tacky, as it supports mucin cracking through connections with disulfide bonds [155]. $\mathrm{H}_{2} \mathrm{~S}$ activates electrolyte absorption via the imitation of ATP-sensitive potassium channels (KATP) and prevents the $\mathrm{Na}+/ \mathrm{K}+$-ATPase and calcium-sensitive potassium channels in human bronchiolar epithelia [156]. The function of exogenous $\mathrm{H}_{2} \mathrm{~S}$ in lung ailments has been considered by using $\mathrm{H}_{2} \mathrm{~S}$ donor representatives. The significance of slow or fast $\mathrm{H}_{2} \mathrm{~S}$-releasing elements in inflammatory reactions was generally evaluated by consuming molecules that are capable of producing $\mathrm{H}_{2} \mathrm{~S}$ with deliberate and continuous discharge kinetics. Treatment with $\mathrm{NaSH}$, "a fast releasing" $\mathrm{H}_{2} \mathrm{~S}$ donor, encourages a significant provocative and inflammatory response in rats, as estimated through amplified MPO activity and the occurrence of leukocytes in the lungs [105].

Furthermore, the slow-releasing $\mathrm{H}_{2} \mathrm{~S}$ elements such as GYY4137 produced antiinflammatory effects in vivo and decreased pro-inflammatory cytokines (IL-I6, IL-I $\beta$, and TNF) in LPS-induced pulmonary inflammation in a mouse model. Similarly, treatment with GYY4137 produces noticeable antioxidant effects by reinstating the antioxidant enzymes catalase and SOD in lung tissues, strengthening the balance between reduced and oxidized GSH [157]. GYY4137 also reduced pro-inflammatory genes' expression via moderating the initiation of NF- $\mathrm{k} \beta$ and IFN regulatory factor-3 (IRF-3) [114]. Post-transcriptional NF- $\mathrm{k} \beta$ is a new mark of $\mathrm{H}_{2} \mathrm{~S}$ to reverse vascular inflammation. $\mathrm{H}_{2} \mathrm{~S}$ blocked the initiation of the NF-к $\beta$ pathways in a model of nanoparticles. Pyrrole induced an inflammatory reaction in pulmonary artery endothelial cells via the sulfidation of IK-к $\beta$ of Cys179 residue, therefore preventing IK-к $\beta$ action. These types of process give clues about defending initiation against pulmonary vascular inflammation, pulmonary arterial hypertension and vascular modeling in vivo [158]. Moreover, treatment with GYY4137 prohibited lung injury and neutrophil migration, decreasing chemoattractant signaling molecules in vitro in the lung tissue of a mouse model of LPS-induced acute lung injury [157]. Remarkably, $\mathrm{H}_{2} \mathrm{~S}$ moderates the entry of leukocytes from the bloodstream to swollen tissues [159], and this consequence depends on the initiation of annexin-1 pro-resolving pathways [160]. $\mathrm{H}_{2} \mathrm{~S}$ considerably reduces pro-inflammatory cytokines such as IL-6 and IL-8 and augmented anti-inflammatory IL-10 in the plasma and lung. $\mathrm{H}_{2} \mathrm{~S}$ directly repressed the pro-inflammatory reaction and ROS development in neutrophils, emphasizing the valuable prospective $\mathrm{H}_{2} \mathrm{~S}$ donors as acute lung injury prophylactics (Figure 4). $\mathrm{H}_{2} \mathrm{~S}$ promotes anti-inflammatory consequences via epigenetic changes.

$\mathrm{H}_{2} \mathrm{~S}$ regulates the methylation and acetylation of histones, which governs the production of pro-inflammatory elements. Hence, $\mathrm{H}_{2} \mathrm{~S}$ contributes to decreasing cytokine discharge and subsequent improvement of LPS in rats $[155,157]$. Treatment with diallyl disulfide (DADS) and arylthioamides as $\mathrm{H}_{2} \mathrm{~S}$ donor induced a protective result in naphthalene-induced lung injury [161,162]. Therapy with DADS increases GSH levels in the lung tissue, preventing pro-inflammatory cytokine (IL-6, IL-8, and TNF) release relating to overcoming lung inflammatory cell deployment and precise neutrophil infiltration [163]. Sulforaphane, a naturally occurring isothiocyanate capable of generating $\mathrm{H}_{2} \mathrm{~S}$ [164], reduced the release of pro-inflammatory mediators in a mouse model of LPS-induced acute lung injury. Sulforaphane mediates lung protection through transcription factor Nrf-2 by regulating mitochondrial function and energy use. Nrf-2 is accountable for inducing the expression of multiple antioxidant genes and averting oxidative injury. This kind of mechanism of action has also been defined for synthetic thiocyanate, whose $\mathrm{H}_{2} \mathrm{~S}$ donor profile has been extensively discussed [147,165-171]. Anethiole dithiolethione has often been an $\mathrm{H}_{2} \mathrm{~S}$ donor or a compound for developing $\mathrm{H}_{2} \mathrm{~S}$-releasing hybrid drugs with the non-steroidal anti-inflammatory agents $\mathrm{H}_{2} \mathrm{~S}$-diclofenac and $\mathrm{H}_{2} \mathrm{~S}$-aspirin. The previously mentioned new drugs possess anti-inflammatory outcomes compared with the "parent drugs" aspirin and diclofenac, showing their efficacy in decreasing lung MPO activity in a rat model of LPS-induced diclofenac-associated septic shock after $\mathrm{H}_{2} \mathrm{~S}$-diclofenac administration [172]. According to a recent study, PM considerably improved airway 
inflammation and emphysema in mice, calculated through the alveolar destruction index, total cell pro-inflammatory cytokinesis (IL-6, IL-8 and TNF), neutrophil counts and CXCL1 broncho-alveolar lavage fluid. $\mathrm{H}_{2} \mathrm{~S}$ decreased particulate matter (PM)-induced mouse emphysema and airway inflammation by decreasing oxidative stress as assessed by 8 -OHdG concentration in lung tissues. $\mathrm{H}_{2} \mathrm{~S}$ plays a protective role in PM-induced rat emphysema and airway inflammation by preventing NLRP3 inflammasome development and apoptosis produced through fine particulate matter(pM2.5) contact with A549 cells but not in Nrf2-silenced cells [173].

Table 1. Pathophysiological actions of $\mathrm{H}_{2} \mathrm{~S}$ in the lung.

\begin{tabular}{|c|c|c|}
\hline Action & $\mathrm{H}_{2} \mathrm{~S}$ & References \\
\hline Vasodilation & $\uparrow$ & {$[153,154]$} \\
\hline Stable asthma & $\downarrow$ & {$[35,36,38,52,68,102,174]$} \\
\hline Bronchodilation & $\uparrow$ & [103] \\
\hline Angiogenic activity & $\uparrow$ & [22] \\
\hline Pro-inflammatory action & $\uparrow$ & [61] \\
\hline Anti-inflammatory action & $\uparrow$ & [61] \\
\hline Airway hyper-reactivity & $\uparrow$ & {$[63,64]$} \\
\hline Asthma exacerbation & $\downarrow$ & {$[35,36,38,52,68,102,174]$} \\
\hline Stable COPD & $\uparrow$ & [65] \\
\hline COPD exacerbation & $\downarrow$ & [37] \\
\hline
\end{tabular}

$\uparrow=$ Increased, $\downarrow=$ decreased.

\section{Clinical Trials of $\mathrm{H}_{2} \mathrm{~S}$ Donors}

Ik-1001(Na2S) was the first compound chosen to administer as an $\mathrm{H}_{2} \mathrm{~S}$ donor in a clinical trial in 2009. Directed IK-1001 (NCT00879645) was the first clinical trial conducted, which was soon terminated, as it was incapable of reducing the sulfide level. Not being capable to consistently measure sulfide is a serious issue for a compound's approval. The main concerns raised by the scientific community were because of the highly volatile and quickly absorbed nature of exogenous sulfide [174]. Numerous sulfide compounds are present in biological systems, and sulfide participates in several chemical processes [175], which reveals that these endogenous compounds are highly dynamic.

In contrast, the exogenous administration of $\mathrm{H}_{2} \mathrm{~S}$ might result in the equilibrium of this entire system in ways that we have not wholly known until now. After that, IK1001(NCT00858936), during secondary trials, affected coronary artery bypass and stopped with this issue. A later clinical trial was established using ST-elevation myocardial infarction (NCT010074610), which was also stopped due to safety issues. Therefore, an aqueous solution of liquid $\mathrm{H}_{2} \mathrm{~S}$ called IK-1001 can be typically administered with $\mathrm{H}_{2} \mathrm{~S}$-releasing salts or inhaled $\mathrm{H}_{2} \mathrm{~S}$. Neither administration of $\mathrm{H}_{2} \mathrm{~S}$ through inhalation nor injection of $\mathrm{H}_{2} \mathrm{~S}$ donors will possibly be utilized in the clinical trials due to airway mucosal injury. Still, there is the possibility of poisonous sulfide concentrations eventually being pro-

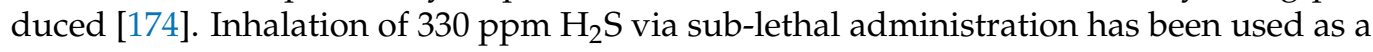
model to study lung injury $[86,176]$. Efforts to evade the airway inflammation of gaseous $\mathrm{H}_{2} \mathrm{~S}$ were applied to an extracorporeal membrane for lung ventilation in a pre-clinical study. However, there was limited development in the effect of cardiopulmonary bypass [100]. The trial utilized a combination of organic sulfide-releasing compounds and salts (named SG-1002(NCT01989208), which has been used in heart failure studies. This trial proved to be safe and well-tolerated in Phase 1 trials; however, it failed in the Phase II (NCT02278276) trial. An excellent prospect for $\mathrm{H}_{2} \mathrm{~S}$-based treatments is the reassessment of $\mathrm{H}_{2} \mathrm{~S}$ donors or compounds that are now clinically permitted and have only recently been recognized to be capable of releasing $\mathrm{H}_{2} \mathrm{~S}$, such as sodium thiosulfate (STS) $[177,178]$, which helped in cyanide detoxification and cisplatin overdosage (ammonium tetra-thiomolybdate (ATTM) $[179,180]$, and is allowed for Wilson's disorder (a copper metabolism ailment), and zofenopril [181], an inhibitor of angiotensin-altering enzymes permitted for hypertension. 
These compounds all have been verified widely and are recognized to have worthy safety profiles. For example, Dyson et al. revealed that ATTM led to a 50\% decrease in infarct size in mouse models of myocardia and cerebral I/ $\mathrm{R}$ in addition to the improved persistence of later hemorrhage [180].

The good wellbeing profile of STS [182], specifically, might be connected to the circumstance that thiosulfate itself is an endogenous intermediate of oxidative $\mathrm{H}_{2} \mathrm{~S}$ metabolism [177] and is recommended as a molecule with valuable $\mathrm{H}_{2} \mathrm{~S}$ results [183], specifically in hypoxic circumstances [177]. The clinical trial of IK-1001 in renal injury utilized thiosulfate as an unintended measure of $\mathrm{H}_{2} \mathrm{~S}$ release by their compound, though this was finally found to be ineffective. STS is presently in a Phase II clinical trial to preserve cardiac function in SREMI. Concerning the lung, as revealed before, STS was helpful in murine models of intratracheal LPS and CLP [80]. While Sakaguchi et al.'s results supported these effects, they determined a practical consequence of STS in the lung, i.e., enhanced gas altercation and lung processes in an interpreter-related large animal model of hemorrhagic shock. Therefore, STS is a compound providing hope for the advancement of therapeutic $\mathrm{H}_{2} \mathrm{~S}$ administration in ALI in clinical settings [80].

In animal experiments, NSAIDs conjugated to $\mathrm{H}_{2} \mathrm{~S}$ (for example, celecoxib and naproxen) revealed a robust protective effect on gastrointestinal epithelium as matched with the parent's lethal drug results [184]. For example, the $\mathrm{H}_{2} \mathrm{~S}$-releasing naproxen known as ATB-346, which releases $\mathrm{H}_{2} \mathrm{~S}$ through a hydrolytic mechanism [184], was confirmed to have better anti-inflammatory results in animal models, decreasing leukocyte migration and decreasing TNF- $\alpha$ and TNF- $\alpha \beta$ expression [184-186]. Another $\mathrm{H}_{2} \mathrm{~S}$ donor is S-mesalamine (ATB-429), which is utilized for the treatment of inflammatory colitis. ATB-429 played a protective role in the gastrointestinal mucosa and had more remarkable anti-inflammatory outcomes than the parent drug [106]. Hence, ATB-429 might be a worthy applicant for decreasing inflammation [187]. Correspondingly, NBS-1120 had an excellent protective role in an animal model of inflammation compared with aspirin [188]. While GYY4137 was show to directly obstruct inflammation in a mouse model by inhibiting different inflammatory molecules [189], GYY4137 can reduce LPS-evoked septic shock [190]. These previously discussed studies emphasized the curative prospects of $\mathrm{H}_{2} \mathrm{~S}$ donors for the treatment of inflammation and respiratory diseases. However, extra in vivo analyses and studies are necessary to endorse the effectiveness of these $\mathrm{H}_{2} \mathrm{~S}$ donors, their safety, and their possible use in such diseases.

\section{Perceptions, Limitations and Prospects}

$\mathrm{H}_{2} \mathrm{~S}$ executes a broad range of pathophysiological functions, including vasodilatation to lower the blood pressure, initiation of angiogenesis, signal regulation of neuronal action and regulation of glucose homeostasis, which have been widely demonstrated beside NO and $\mathrm{CO} . \mathrm{H}_{2} \mathrm{~S}$ was previously considered an environmental contaminant but is now widely recognized as an important biological and pharmacological medium, and is considered to be the third endogenous gas transmitter in mammals, There is increasing confirmation that $\mathrm{H}_{2} \mathrm{~S}$ plays a crucial part in respiratory diseases, revealing that the metabolic machinery and mechanisms of $\mathrm{H}_{2} \mathrm{~S}$ are an essential research topic in respiratory diseases. $\mathrm{H}_{2} \mathrm{~S}$ is mainly metabolized by CSE, CBS and 3-MST in mammals. The metabolic pathway of $\mathrm{H}_{2} \mathrm{~S}$ is different in different organs and tissues. There is increasing evidence that $\mathrm{H}_{2} \mathrm{~S}$ plays a crucial role in respiratory diseases. Investigating the metabolic machinery and mechanisms of $\mathrm{H}_{2} \mathrm{~S}$ in respiratory diseases is an important research topic that may help develop new drugs. The scientific relationships of $\mathrm{H}_{2} \mathrm{~S}$ in mammals should be widely observed and studied experimentally to elucidate the expression and function of $\mathrm{H}_{2} \mathrm{~S}$-producing enzymes in different organs and tissues, and provide new ideas for the better development of new $\mathrm{H}_{2} \mathrm{~S}$ donors and targeted clinical therapies.

Respiratory disorders are general and often-occurring ailments with a relatively high mortality rate. The primary lesions are in the trachea, bronchus, lungs and chest. In addition to the existing pathophysiological mechanisms, further research into and clarification of 
the new underlying mechanisms and new signaling pathways associated with respiratory diseases are needed. At present, some progress has been made by using animal models to study the molecular mechanism of $\mathrm{H}_{2} \mathrm{~S}$ in respiratory injury. The molecular targets of $\mathrm{H}_{2} \mathrm{~S}$ in the respiratory system also require further investigation. Because altered amounts of $\mathrm{H}_{2} \mathrm{~S}$-releasing compounds may produce various therapeutic outcomes, further appropriate dose ranges should be studied to achieve better therapeutic results. Moreover, new $\mathrm{H}_{2} \mathrm{~S}-$ releasing donors should be designed and identified to increase the therapeutic effect by mediating $\mathrm{H}_{2} \mathrm{~S}$ concentrations in human disease, and whether this effect would reduce long-term disease and mortality.

The present evidence proposes that $\mathrm{H}_{2} \mathrm{~S}$ has a function in regulating and maintaining vital biological progressions in animals. Despite the noteworthy development of $\mathrm{H}_{2} \mathrm{~S}$ donors, there is still an absence of compounds that can address all the requirements for the perfect $\mathrm{H}_{2} \mathrm{~S}$ donor in clinical studies. There are major gaps in our understanding that obstruct the clinical usage of $\mathrm{H}_{2} \mathrm{~S}$ donors. Many questions need to be answered, such as (i) what the $\mathrm{H}_{2} \mathrm{~S}$-releasing compounds are, (ii) the therapeutic concentrations of $\mathrm{H}_{2} \mathrm{~S}$ and its compounds, (iii) the concentrations at which $\mathrm{H}_{2} \mathrm{~S}$ and its donors become toxic, (iv) the level of toxicity, (v) the mechanisms of $\mathrm{H}_{2} \mathrm{~S}$ release from the $\mathrm{H}_{2} \mathrm{~S}$ donors and drugs, (vi) the administration of $\mathrm{H}_{2} \mathrm{~S}$ in vivo at a constant rate, (vii) the mechanism action of $\mathrm{H}_{2} \mathrm{~S}$, (viii) the monitoring of plasma levels of $\mathrm{H}_{2} \mathrm{~S}$ and its products, (ix) what the differences between $\mathrm{H}_{2} \mathrm{~S}$ administration in vivo and in vitro are, (x) assessing the sensitivity and specificity of $\mathrm{H}_{2} \mathrm{~S}$, (xi) the selection of patients for assessing the effectiveness of $\mathrm{H}_{2} \mathrm{~S}$ drugs, and (xii) finding appropriate doses of $\mathrm{H}_{2} \mathrm{~S}$ or its donors for treatment over a reasonable period in respiratory disease, and in pre-clinical and clinical studies. In conclusion, a deeper understanding of the exact molecular mechanisms behind the role of $\mathrm{H}_{2} \mathrm{~S}$ in the development, progression, prevention and treatment of respiratory diseases is important for using appropriate doses of $\mathrm{H}_{2} \mathrm{~S}$ or its donors to improve its clinical efficacy.

Author Contributions: D.-D.W. and X.-Y.J. conceived the concept of the review and supervised the project. S.K., Q.-Q.Z., M.S., P.M., E.E.N., N.H.K., S.R., Y.-Z.W., H.-W.Q., and D.W. reviewed the literatures and extracted the data. S.K. and Q.-Q.Z. drafted the manuscript. D.-D.W., A.A. and X.-Y.J. revised the manuscript and provided intellectual input in the review. All authors have read and agreed to the published version of the manuscript.

Funding: This work was supported by the National Natural Science Foundation of China (Nos 81802718 and U1504817), the Foundation of Science and Technology Department of Henan Province, China (Nos 192102310151 and 202102310480) and the Training Program for Young Backbone Teachers of Institution of Higher Learning in Henan Province, China (No. 2020GGJS038).

Conflicts of Interest: The authors declare no conflict of interest.

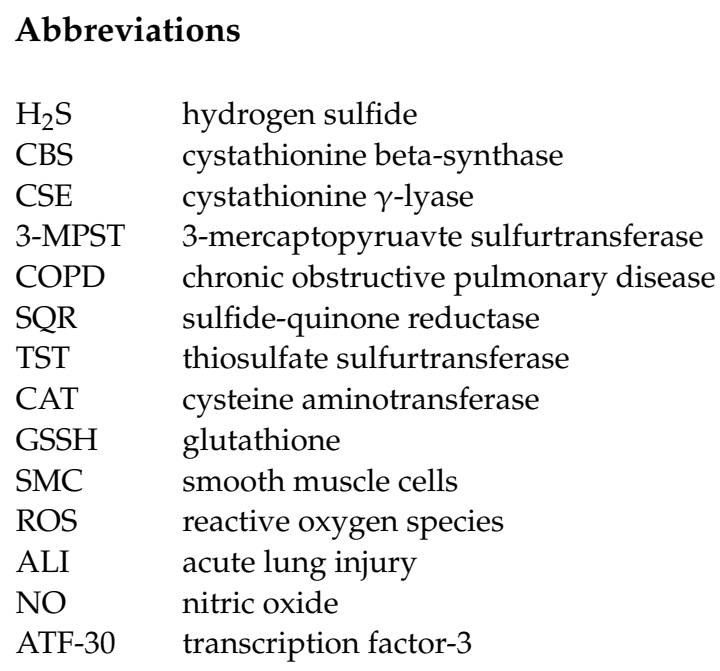




$\begin{array}{ll}\text { OA } & \text { oleic acid } \\ \text { ECM } & \text { extracellular matrix } \\ \text { MLC } & \text { myosin light chain } \\ \text { PHT } & \text { pulmonary hypertension } \\ \text { SM } & \text { sulfur mustard } \\ \text { NSAID } & \text { non-steroidal anti-inflammatory drugs } \\ \text { MODS } & \text { multiple organ dysfunction syndrome } \\ \text { MDA } & \text { malondialdehyde } \\ \text { MPO } & \text { myeloperoxidase } \\ \text { ARDS } & \text { acute respiratory distress syndrome } \\ \text { LPVS } & \text { lung-protective ventilation strategies } \\ \text { VILI } & \text { ventilator-induced lung injury } \\ \text { FEV } & \text { forced expiratory volume } \\ \text { LTx } & \text { lung transplantation } \\ \text { PH } & \text { pulmonary hypertension } \\ \text { RSV } & \text { respiratory syncytial virus } \\ \text { IPF } & \text { idiopathic pulmonary fibrosis } \\ \text { CSAS } & \text { central sleep apnea syndrome } \\ \text { SAS } & \text { sleep apnea syndrome } \\ \text { hMPV } & \text { human metapneumovirus } \\ \text { CB } & \text { carotid body } \\ \text { CO } & \text { carbon monoxide } \\ \text { BPD } & \text { bronchopulmonary dysplasia } \\ \text { ATII } & \text { alveolar Type II } \\ \text { NaHS } & \text { sodium hydrosulfide } \\ \text { HO-1 } & \text { heme oxygenase-1 } \\ \text { STAT-3 } & \text { signal transducer and activator of transporter-1 } \\ \text { Nrf-2 } & \text { nuclear factor erythroid-2 related factor } \\ \text { NF-K } \beta & \text { nuclear factor-kappa B } \\ \text { PI3K } & \text { phosphoinositide 3-kinase } \\ \text { ERK } & \text { extracellular signal-regulated kinase } \\ \text { AMPK } & \text { AMP-activated protein kinase } \\ \text { TNF- } \alpha & \text { tumor necrosis factor- } \alpha \\ \text { TGF- } \beta 1 & \text { transforming growth factor beta 1 } \\ \text { SOD } & \text { superoxide dismutase } \\ \text { IL } & \text { interleukin } \\ \text { IKK } & \text { IkB kinase } \\ \text { Keap1 } & \text { Kelch-like-ECH-associated protein } \\ \text { ADT-OH } & \text { 5-(hydroxyphenyl)-3H-1:2-dithiole-3-thione } \\ \text { ATB-429 } & \text { 4-(5-sulfanylidenedithiol-3-y) phenyl 5-amino-2-hydroxybenzoate } \\ \text { STS } & \text { sodium thiosulfate } \\ & \end{array}$

\section{References}

1. Scano, G.; Innocenti-Bruni, G.; Stendardi, L. Do obstructive and restrictive lung diseases share common underlying mechanisms of breathlessness? Respir. Med. 2010, 104, 925-933. [CrossRef] [PubMed]

2. Dasaraju, P.V.; Liu, C. Infections of the Respiratory System, 4th ed.; University of Texas Medical Branch at Galveston: Galveston, TX, USA, 1996.

3. Bartlett, J.G. Management of Respiratory Tract Infections; Williams \& Wilkins: Baltimore, MD, USA, 1997.

4. Perez-Padilla, R.P.B.; Marks, G.; Wong, G.; Bateman, E.; Jarvis, D.; Prabhakaran, D.; Anand, S.; Gaziano, T.A.; Mbanya, J.-C.; Wu, Y.; et al. Chronic Lower Respiratory Tract Diseases. In Cardiovascular, Respiratory, and Related Disorders, 3rd ed.; World Bank: Washington, DC, USA, 2017; Volume 5, pp. 263-285.

5. Zar, H.J.; Ferkol, T.W. The global burden of respiratory disease-Impact on child health. Pediatr. Pulmonol. 2014, 49, 430-434. [CrossRef]

6. World Health Organization. WHO Strategy for Prevention and Control of Chronic Respiratory Diseases; World Health Organization: Geneva, Switzerland, 2002.

7. Abou-Hamdan, A.; Guedouari-Bounihi, H.; Lenoir, V.; Andriamihaja, M.; Blachier, F.; Bouillaud, F. Oxidation of $\mathrm{H}_{2} \mathrm{~S}$ in Mammalian Cells and Mitochondria. Methods Enzymol. 2015, 554, 201-228. [CrossRef] [PubMed]

8. Ramazzini, B. De morbis artificum Bernardini Ramazzini diatribe; University of Chicago Press: Chicago, IL, USA, 1940. 
9. Reiffenstein, R.J.; Hulbert, W.C.; Roth, S.H. Toxicology of hydrogen sulfide. Annu. Rev. Pharmacol. Toxicol. 1992, 32, 109-134. [CrossRef]

10. Bhatia, M.; Wong, F.L.; Fu, D.; Lau, H.Y.; Moochhala, S.M.; Moore, P.K. Role of hydrogen sulfide in acute pancreatitis and associated lung injury. FASEB J. 2005, 19, 1-17. [CrossRef]

11. Wu, D.; Luo, N.; Wang, L.; Zhao, Z.; Bu, H.; Xu, G.; Yan, Y.; Che, X.; Jiao, Z.; Zhao, T.; et al. Hydrogen sulfide ameliorates chronic renal failure in rats by inhibiting apoptosis and inflammation through ROS/MAPK and NF-кB signaling pathways. Sci. Rep. 2017, 7, 455. [CrossRef]

12. Li, L.; Moore, P.K. Could hydrogen sulfide be the next blockbuster treatment for inflammatory disease? Expert Rev. Clin. Pharmacol. 2013, 6, 593-595. [CrossRef] [PubMed]

13. Fiorucci, S. Hydrogen sulfide: From physiology to pharmacology. Inflamm. Allergy Drug Targets 2011, 10, 77-84. [CrossRef] [PubMed]

14. Abe, K.; Kimura, H. The possible role of hydrogen sulfide as an endogenous neuromodulator. J. Neurosci. 1996, 16, 1066-1071. [CrossRef] [PubMed]

15. Wu, D.; Wang, J.; Li, H.; Xue, M.; Ji, A.; Li, Y. Role of Hydrogen Sulfide in Ischemia-Reperfusion Injury. Oxidative Med. Cell. Longev. 2015, 2015, 1-16. [CrossRef]

16. Zhong, G.Z.; Chen, F.R.; Cheng, Y.Q.; Tang, C.S.; Du, J.B. The role of hydrogen sulfide generation in the pathogenesis of hypertension in rats induced by inhibition of nitric oxide synthase. J. Hypertens. 2003, 21, 1879-1885. [CrossRef]

17. Szabo, C.; Coletta, C.; Chao, C.; Módis, K.; Szczesny, B.; Papapetropoulos, A.; Hellmich, M.R. Tumor-derived hydrogen sulfide, produced by cystathionine- $\beta$-synthase, stimulates bioenergetics, cell proliferation, and angiogenesis in colon cancer. Proc. Natl. Acad. Sci. USA 2013, 110, 12474-12479. [CrossRef]

18. Bhattacharyya, S.; Saha, S.; Giri, K.; Lanza, I.R.; Nair, K.S.; Jennings, N.B.; Rodriguez-Aguayo, C.; Lopez-Berestein, G.; Basal, E.; Weaver, A.L.; et al. Cystathionine Beta-Synthase (CBS) Contributes to Advanced Ovarian Cancer Progression and Drug Resistance. PLoS ONE 2013, 8, e79167. [CrossRef] [PubMed]

19. Sen, S.; Kawahara, B.; Gupta, D.; Tsai, R.; Khachatryan, M.; Roy-Chowdhuri, S.; Bose, S.; Yoon, A.; Faull, K.; Farias-Eisner, R.; et al. Role of cystathionine $\beta$-synthase in human breast Cancer. Free. Radic. Biol. Med. 2015, 86, 228-238. [CrossRef] [PubMed]

20. Panza, E.; De Cicco, P.; Armogida, C.; Scognamiglio, G.; Gigantino, V.; Botti, G.; Germano, D.; Napolitano, M.; Papapetropoulos, A.; Bucci, M. Role of the cystathionine $\gamma$ lyase/hydrogen sulfide pathway in human melanoma progression. Pigment Cell Melanoma Res. 2015, 28, 61-72. [CrossRef] [PubMed]

21. Baskar, R.; Bian, J. Hydrogen sulfide gas has cell growth regulatory role. Eur. J. Pharmacol. 2011, 656, 5-9. [CrossRef]

22. Coletta, C.; Papapetropoulos, A.; Erdelyi, K.; Olah, G.; Modis, K.; Panopoulos, P.; Asimakopoulou, A.; Gero, D.; Sharina, I.; Martin, E.; et al. Hydrogen sulfide and nitric oxide are mutually dependent in the regulation of angiogenesis and endothelium-dependent vasorelaxation. Proc. Natl. Acad. Sci. USA 2012, 109, 9161-9166. [CrossRef]

23. Szabo, C. Gasotransmitters in cancer: From pathophysiology to experimental therapy. Nat. Rev. Drug Discov. 2016, 15, 185-203. [CrossRef] [PubMed]

24. Módis, K.; Coletta, C.; Asimakopoulou, A.; Szczesny, B.; Chao, C.; Papapetropoulos, A.; Hellmich, M.R.; Szabo, C. Effect of S-adenosyl-L-methionine (SAM), an allosteric activator of cystathionine- $\beta$-synthase (CBS) on colorectal cancer cell proliferation and bioenergetics in vitro. Nitric Oxide 2014, 41, 146-156. [CrossRef]

25. Szabó, C.; Papapetropoulos, A. Hydrogen sulphide and angiogenesis: Mechanisms and applications. Br. J. Pharmacol. 2011, 164, 853-865. [CrossRef]

26. Szczesny, B.; Módis, K.; Yanagi, K.; Coletta, C.; Le Trionnaire, S.; Perry, A.; Wood, M.E.; Whiteman, M.; Szabo, C. AP39, a novel mitochondria-targeted hydrogen sulfide donor, stimulates cellular bioenergetics, exerts cytoprotective effects and protects against the loss of mitochondrial DNA integrity in oxidatively stressed endothelial cells in vitro. Nitric Oxide 2014, 41, 120-130. [CrossRef]

27. Wang, M.-J.; Cai, W.-J.; Li, N.; Ding, Y.-J.; Chen, Y.; Zhu, Y.-C. The Hydrogen Sulfide Donor NaHS Promotes Angiogenesis in a Rat Model of Hind Limb Ischemia. Antioxid. Redox Signal. 2010, 12, 1065-1077. [CrossRef] [PubMed]

28. Yang, G.; Sun, X.; Wang, R. Hydrogen sulfide-induced apoptosis of human aorta smooth muscle cells via the activation of mitogen-activated protein kinases and caspase-3. Faseb J. 2004, 18, 1782-1784. [CrossRef]

29. Sen, N.; Paul, B.D.; Gadalla, M.M.; Mustafa, A.K.; Sen, T.; Xu, R.; Kim, S.; Snyder, S.H. Hydrogen sulfide-linked sulfhydration of NF- $\mathrm{kB}$ mediates its antiapoptotic actions. Mol. Cell 2012, 45, 13-24. [CrossRef] [PubMed]

30. Cai, W.-J.; Wang, M.-J.; Moore, P.K.; Jin, H.-M.; Yao, T.; Zhu, Y.-C. The novel proangiogenic effect of hydrogen sulfide is dependent on Akt phosphorylation. Cardiovasc. Res. 2007, 76, 29-40. [CrossRef] [PubMed]

31. Isenberg, J.S.; Jia, Y.; Field, L.; A Ridnour, L.; Sparatore, A.; Del Soldato, P.; Sowers, A.L.; Yeh, G.C.; Moody, T.W.; A Wink, D.; et al. Modulation of angiogenesis by dithiolethione-modified NSAIDs and valproic acid. Br. J. Pharmacol. 2007, 151, 142-151. [CrossRef] [PubMed]

32. Papapetropoulos, A.; Pyriochou, A.; Altaany, Z.; Yang, G.; Marazioti, A.; Zhou, Z.; Jeschke, M.G.; Branski, L.K.; Herndon, D.N.; Wang, R.; et al. Hydrogen sulfide is an endogenous stimulator of angiogenesis. Proc. Natl. Acad. Sci. USA 2009, 106, 21972-21977. [CrossRef] [PubMed]

33. Kimura, Y.; Goto, Y.-I.; Kimura, H. Hydrogen Sulfide Increases Glutathione Production and Suppresses Oxidative Stress in Mitochondria. Antioxid. Redox Signal. 2010, 12, 1-13. [CrossRef] [PubMed] 
34. Wu, D.; Zheng, N.; Ziqiang, S.; Cheng, H.; Sun, Z.; Gao, B.; Zhang, Y.; Pang, W.; Huangfu, C.; Ji, S.; et al. Exogenous hydrogen sulfide mitigates the fatty liver in obese mice through improving lipid metabolism and antioxidant potential. Med. Gas. Res. 2015, 5, 1-8. [CrossRef] [PubMed]

35. Chen, J.; Zhang, H.; Yu, W.; Chen, L.; Wang, Z.; Zhang, T. Expression of pulmonary arterial elastin in rats with hypoxic pulmonary hypertension using $\mathrm{H}_{2}$ S. J. Recept. Signal. Transduct. 2020, 40, 383-387. [CrossRef]

36. Chen, Y.-H.; Wu, R.; Geng, B.; Qi, Y.-F.; Wang, P.-P.; Yao, W.-Z.; Tang, C.-S. Endogenous hydrogen sulfide reduces airway inflammation and remodeling in a rat model of asthma. Cytokine 2009, 45, 117-123. [CrossRef]

37. Chen, Y.-H.; Yao, W.-Z.; Geng, B.; Ding, Y.-L.; Lu, M.; Zhao, M.-W.; Tang, C.-S. Endogenous Hydrogen Sulfide in Patients With COPD. Chest 2005, 128, 3205-3211. [CrossRef]

38. Zhang, J.; Wang, X.; Chen, Y.; Yao, W. Correlation between levels of exhaled hydrogen sulfide and airway inflammatory phenotype in patients with chronic persistent asthma. Respirology 2014, 19, 1165-1169. [CrossRef]

39. Han, W.; Dong, Z.; Dimitropoulou, C.; Su, Y. Hydrogen Sulfide Ameliorates Tobacco Smoke-Induced Oxidative Stress and Emphysema in Mice. Antioxid. Redox Signal. 2011, 15, 2121-2134. [CrossRef] [PubMed]

40. Chen, L.; Zhang, J.; Ding, Y.; Li, H.; Nie, L.; Yan, X.; Zhou, H.; Zheng, Y. KATP channels of parafacial respiratory group (pFRG) neurons are involved in $\mathrm{H}_{2} \mathrm{~S}$-mediated central inhibition of respiratory rhythm in medullary slices of neonatal rats. Brain Res. 2013, 1527, 141-148. [CrossRef] [PubMed]

41. Iciek, M.; Bilska-Wilkosz, A.; Górny, M. Sulfane sulfur-New findings on an old topic. Acta Biochim. Pol. 2019, 66, 533-544. [CrossRef]

42. Ishigami, M.; Hiraki, K.; Umemura, K.; Ogasawara, Y.; Ishii, K.; Kimura, H. A Source of Hydrogen Sulfide and a Mechanism of Its Release in the Brain. Antioxid. Redox Signal. 2009, 11, 205-214. [CrossRef]

43. Toohey, J.I. Sulfur signaling: Is the agent sulfide or sulfane? Anal. Biochem. 2011, 413, 1-7. [CrossRef]

44. Toohey, J.I. The conversion of $\mathrm{H}_{2} \mathrm{~S}$ to sulfane sulfur. Nat. Rev. Mol. Cell Biol. 2012, 13, 803. [CrossRef] [PubMed]

45. Szabo, C. Hydrogen sulfide, an enhancer of vascular nitric oxide signaling: Mechanisms and implications. Am. J. Physiol. Physiol. 2017, 312, C3-C15. [CrossRef] [PubMed]

46. Zheng, Y.; Yu, B.; De La Cruz, L.K.; Choudhury, M.R.; Anifowose, A.; Wang, B. Toward Hydrogen Sulfide Based Therapeutics: Critical Drug Delivery and Developability Issues. Med. Res. Rev. 2018, 38, 57-100. [CrossRef]

47. Gojon, G.; Morales, G.A. SG1002 and Catenated Divalent Organic Sulfur Compounds as Promising Hydrogen Sulfide Prodrugs. Antioxid. Redox Signal. 2020, 33, 1010-1045. [CrossRef] [PubMed]

48. Olhemus, D.J.; Li, Z.; Pattillo, C.B.; Gojon, G., Sr.; Gojon, G., Jr.; Giordano, T.; Krum, H. AA Novel Hydrogen Sulfide Prodrug, SG1002, Promotes Hydrogen Sulfide and Nitric Oxide Bioavailability in Heart Failure Patients. Cardiovasc Ther. 2015, 33, 216-226. [CrossRef]

49. Jiang, X.; Liu, Y.; Ma, L.; Ji, R.; Qu, Y.; Xin, Y.; Lv, G. Chemopreventive activity of sulforaphane. Drug Des. Dev. Ther. 2018, 12, 2905-2913. [CrossRef] [PubMed]

50. Szabó, C. Hydrogen sulphide and its therapeutic potential. Nat. Rev. Drug Discov. 2007, 6, 917-935. [CrossRef]

51. Madden, J.A.; Ahlf, S.B.; Dantuma, M.W.; Olson, K.R.; Roerig, D.L. Precursors and inhibitors of hydrogen sulfide synthesis affect acute hypoxic pulmonary vasoconstriction in the intact lung. J. Appl. Physiol. 2012, 112, 411-418. [CrossRef] [PubMed]

52. Wang, P.; Zhang, G.; Wondimu, T.; Ross, B.; Wang, R. Hydrogen sulfide and asthma. Exp. Physiol. 2011, 96, 847-852. [CrossRef]

53. Mustafa, A.K.; Gadalla, M.M.; Sen, N.; Kim, S.; Mu, W.; Gazi, S.K.; Barrow, R.K.; Yang, G.; Wang, R.; Snyder, S.H. H 2 S Signals Through Protein S-Sulfhydration. Sci. Signal. 2009, 2, ra72. [CrossRef]

54. Ju, Y.; Untereiner, A.; Wu, L.; Yang, G. $\mathrm{H}_{2} \mathrm{~S}$-induced S-sulfhydration of pyruvate carboxylase contributes to gluconeogenesis in liver cells. Biochim. Biophys. Acta 2015, 1850, 2293-2303. [CrossRef] [PubMed]

55. Pauwels, R.A.; Buist, A.S.; Calverley, P.M.; Jenkins, C.R.; Hurd, S.S. Global strategy for the diagnosis, management, and prevention of chronic obstructive pulmonary disease: NHLBI/WHO Global Initiative for Chronic Obstructive Lung Disease (GOLD) Workshop summary. Am. J. Respir. Crit. Care. Med. 2001, 163, 1256-1276. [CrossRef]

56. Wang, L.; Meng, J.; Wang, C.; Yang, C.; Wang, Y.; Li, Y.; Li, Y. Hydrogen sulfide alleviates cigarette smoke-induced COPD through inhibition of the TGF- $\beta 1 /$ smad pathway. Exp. Biol. Med. 2020, 245, 190-200. [CrossRef]

57. Viegas, J.; Esteves, A.F.; Cardoso, E.M.; Arosa, F.A.; Vitale, M.; Taborda-Barata, L. Biological Effects of Thermal Water-Associated Hydrogen Sulfide on Human Airways and Associated Immune Cells: Implications for Respiratory Diseases. Front. Public Heal. 2019, 7, 128. [CrossRef]

58. Whiteman, M.; Winyard, P.G. Hydrogen sulfide and inflammation: The good, the bad, the ugly and the promising. Expert Rev. Clin. Pharmacol. 2011, 4, 13-32. [CrossRef] [PubMed]

59. Li, T.; Zhao, B.; Wang, C.; Wang, H.; Liu, Z.; Li, W.; Jin, H.; Tang, C.; Du, J. Regulatory Effects of Hydrogen Sulfide on IL-6, IL-8 and IL-10 Levels in the Plasma and Pulmonary Tissue of Rats with Acute Lung Injury. Exp. Biol. Med. 2008, 233, $1081-1087$. [CrossRef] [PubMed]

60. Grommes, J.; Soehnlein, O. Contribution of Neutrophils to Acute Lung Injury. Mol. Med. 2011, 17, 293-307. [CrossRef] [PubMed]

61. Esechie, A.; Kiss, L.; Olah, G.; Horvath, E.; Hawkins, H.; Szabo, C.; Traber, D. Protective effect of hydrogen sulfide in a murine model of combined burn and smoke inhalation-induced acute lung injury. Clin. Sci. 2008, 115, 91-97. [CrossRef]

62. Rose, P.; Moore, P.K.; Zhu, Y.Z. $\mathrm{H}_{2} \mathrm{~S}$ biosynthesis and catabolism: New insights from molecular studies. Cell. Mol. Life Sci. 2017, 74, 1391-1412. [CrossRef] 
63. Chen, Y.-H.; Wang, P.-P.; Wang, X.-M.; He, Y.-J.; Yao, W.-Z.; Qi, Y.-F.; Tang, C.-S. Involvement of endogenous hydrogen sulfide in cigarette smoke-induced changes in airway responsiveness and inflammation of rat lung. Cytokine 2011, 53, 334-341. [CrossRef]

64. Roviezzo, F.; Bertolino, A.; Sorrentino, R.; Terlizzi, M.; Matteis, M.; Calderone, V.; Mattera, V.; Martelli, A.; Spaziano, G.; Pinto, A.; et al. Hydrogen sulfide inhalation ameliorates allergen induced airway hypereactivity by modulating mast cell activation. Pharmacol. Res. 2015, 100, 85-92. [CrossRef]

65. Saito, J.; Mackay, A.J.; Rossios, C.; Gibeon, D.; Macedo, P.; Sinharay, R.; Bhavsar, P.K.; A Wedzicha, J.; Chung, K.F. Sputum-to-serum hydrogen sulfide ratio in COPD. Thorax 2014, 69, 903-909. [CrossRef] [PubMed]

66. Perry, M.M.; Tildy, B.; Papi, A.; Casolari, P.; Caramori, G.; Rempel, K.L.; Halayko, A.J.; Adcock, I.; Chung, K.F. The antiproliferative and anti-inflammatory response of COPD airway smooth muscle cells to hydrogen sulfide. Respir. Res. 2018, 19, 1-10. [CrossRef] [PubMed]

67. Kirkham, P.A.; Whiteman, M.; Winyard, P.G.; Caramori, G.; Gordon, F.; Ford, P.A.; Barnes, P.J.; Adcock, I.M.; Chung, K.F. Impact of theophylline/corticosteroid combination therapy on sputum hydrogen sulfide levels in patients with COPD. Eur. Respir. J. 2014, 43, 1504-1506. [CrossRef]

68. Zhang, J.; Wang, X.; Chen, Y.; Yao, W.; Rosner, E.; Mastropietro, C.W. Exhaled Hydrogen Sulfide Predicts Airway Inflammation Phenotype in COPD. Respir. Care 2014, 60, 251-258. [CrossRef] [PubMed]

69. Chen, Y.; Liu, S.; Yao, W. Imbalance of Endogenous Hydrogen Sulfide and Homocysteine Pathway in Chronic Obstructive Pulmonary Disease Combined with Cardiovascular Disease. In Proceedings of the American Thoracic Society 2012 International Conference, San Francisco, CA, USA, 18-23 May 2012; American Thoracic Society: New York, NY, USA, 2012; p. 3985.

70. Fitzgerald, R.; DeSantiago, B.; Lee, D.Y.; Yang, G.; Kim, J.Y.; Foster, D.B.; Chan-Li, Y.; Horton, M.R.; Panettieri, R.A.; Wang, R.; et al. $\mathrm{H}_{2} \mathrm{~S}$ relaxes isolated human airway smooth muscle cells via the sarcolemmal KATP channel. Biochem. Biophys. Res. Commun. 2014, 446, 393-398. [CrossRef]

71. Wheeler, A.P.; Bernard, G.R. Acute lung injury and the acute respiratory distress syndrome: A clinical review. Lancet 2007, 369, 1553-1564. [CrossRef]

72. Mackay, A.; Al-Haddad, M. Acute lung injury and acute respiratory distress syndrome. Contin. Educ. Anaesth. Crit. Care Pain 2009, 9, 152-156. [CrossRef]

73. Ge, X.; Sun, J.; Fei, A.; Gao, C.; Pan, S.; Wu, Z. Hydrogen sulfide treatment alleviated ventilator-induced lung injury through regulation of autophagy and endoplasmic reticulum stress. Int. J. Biol. Sci. 2019, 15, 2872-2884. [CrossRef]

74. Spassov, S.G.; Donus, R.; Ihle, P.M.; Engelstaedter, H.; Hoetzel, A.; Faller, S. Hydrogen sulfide prevents formation of reactive oxygen species through PI3K/Akt signaling and limits ventilator-induced lung injury. Oxid. Med. Cell. Longev. 2017, 2017, 3715037. [CrossRef] [PubMed]

75. Zhang, H.-X.; Liu, S.-J.; Tang, X.-L.; Duan, G.-L.; Ni, X.; Zhu, X.-Y.; Liu, Y.-J.; Wang, C.-N. H2S Attenuates LPS-Induced Acute Lung Injury by Reducing Oxidative/Nitrative Stress and Inflammation. Cell. Physiol. Biochem. 2016, 40, 1603-1612. [CrossRef]

76. Faller, S.; Zimmermann, K.K.; Strosing, K.M.; Engelstaedter, H.; Buerkle, H.; Schmidt, R.; Spassov, S.G.; Hoetzel, A. Inhaled hydrogen sulfide protects against lipopolysaccharide-induced acute lung injury in mice. Med. Gas. Res. 2012, 2, 26. [CrossRef]

77. Zimmermann, K.K.; Spassov, S.G.; Strosing, K.M.; Ihle, P.M.; Engelstaedter, H.; Hoetzel, A.; Faller, S. Hydrogen Sulfide Exerts Anti-oxidative and Anti-inflammatory Effects in Acute Lung Injury. Inflammation 2017, 41, 249-259. [CrossRef]

78. Han, Z.-H.; Jiang, Y.; Duan, Y.-Y.; Wang, X.-Y.; Huang, Y.; Fang, T.-Z. Protective effects of hydrogen sulfide inhalation on oxidative stress in rats with cotton smoke inhalation-induced lung injury. Exp. Ther. Med. 2015, 10, 164-168. [CrossRef] [PubMed]

79. Qi, Q.Y.C.; Chen, W.; Li, X.L.; Wang, Y.W.; Xie, X.H. $\mathrm{H}_{2} \mathrm{~S}$ protecting against lung injury following limb ischemia-reperfusion by alleviating inflammation and water transport abnormality in rats. Biomed. Environ. Sci. 2014, 27, 410-418. [PubMed]

80. Sakaguchi, M.; Marutani, E.; Shin, H.-s.; Chen, W.; Hanaoka, K.; Xian, M.; Ichinose, F. Sodium thiosulfate attenuates acute lung injury in mice. Anesthesiology 2014, 121, 1248-1257. [CrossRef] [PubMed]

81. Spassov, S.; Pfeifer, D.; Strosing, K.; Ryter, S.; Hummel, M.; Faller, S.; Hoetzel, A. Genetic Targets of Hydrogen Sulfide in Ventilator-Induced Lung Injury-A Microarray Study. PLoS ONE 2014, 9, e102401. [CrossRef]

82. Geng, P.; Ma, T.; Xing, J.; Jiang, L.; Sun, H.; Zhu, B.; Zhang, H.; Xiao, H.; Wang, J.; Zhang, J. Dexamethasone ameliorates $\mathrm{H}_{2} \mathrm{~S}$-induced acute lung injury by increasing claudin-5 expression via the PI3K pathway. Hum. Exp. Toxicol. 2017, 37, 626-635. [CrossRef]

83. Ning, J.; Mo, L.; Zhao, H.; Lu, K.; Lai, X.; Luo, X.; Zhao, H.; Ma, D. Sodium Hydrosulphide Alleviates Remote Lung Injury Following Limb Traumatic Injury in Rats. PLoS ONE 2013, 8, e59100. [CrossRef] [PubMed]

84. Vadivel, A.; Alphonse, R.S.; Ionescu, L.; Machado, D.S.; O’Reilly, M.; Eaton, F.; Haromy, A.; Michelakis, E.D.; Thébaud, B. Exogenous Hydrogen Sulfide $\left(\mathrm{H}_{2} \mathrm{~S}\right)$ Protects Alveolar Growth in Experimental O2-Induced Neonatal Lung Injury. PLoS ONE 2014, 9, e90965. [CrossRef]

85. Liu, Z.-W.; Wang, H.-Y.; Guan, L.; Zhao, B. Regulatory effects of hydrogen sulfide on alveolar epithelial cell endoplasmic reticulum stress in rats with acute lung injury. World J. Emerg. Med. 2015, 6, 67-73. [CrossRef]

86. Wang, J.; Zhang, H.; Su, C.; Chen, J.; Zhu, B.; Zhang, H.; Xiao, H.; Zhang, J. Dexamethasone Ameliorates $\mathrm{H}_{2} \mathrm{~S}-\mathrm{Induced}$ Acute Lung Injury by Alleviating Matrix Metalloproteinase-2 and -9 Expression. PLoS ONE 2014, 9, e94701. [CrossRef] [PubMed]

87. Aslami, H.; Heinen, A.; Roelofs, J.J.T.H.; Zuurbier, C.J.; Schultz, M.J.; Juffermans, N.P. Suspended animation inducer hydrogen sulfide is protective in an in vivo model of ventilator-induced lung injury. Intensiv. Care Med. 2010, 36, 1946-1952. [CrossRef] [PubMed] 
88. Shields, C.J.; Winter, D.C.; Redmond, H.P. Lung injury in acute pancreatitis: Mechanisms, prevention, and therapy. Curr. Opin. Crit. Care 2002, 8, 158-163. [CrossRef]

89. Bhatia, M.; Sidhapuriwala, J.N.; Sparatore, A.; Moore, P.K. Treatment with $\mathrm{H}_{2} \mathrm{~S}$-releasing diclofenac protects mice against acute pancreatitis-associated lung injury. Shock 2008, 29, 84-88. [CrossRef] [PubMed]

90. Tamizhselvi, R.; Moore, P.K.; Bhatia, M. Inhibition of Hydrogen Sulfide Synthesis Attenuates Chemokine Production and Protects Mice against Acute Pancreatitis and Associated Lung Injury. Pancreas 2008, 36, e24-e31. [CrossRef] [PubMed]

91. Meng, W.; Pei, Z.; Feng, Y.; Zhao, J.; Chen, Y.; Shi, W.; Xu, Q.; Lin, F.; Sun, M.; Xiao, K. Neglected role of hydrogen sulfide in sulfur mustard poisoning: Keap1 S-sulfhydration and subsequent Nrf2 pathway activation. Sci. Rep. 2017, 7, 1-17. [CrossRef] [PubMed]

92. Bhatia, M.; Zhi, L.; Zhang, H.; Ng, S.-W.; Moore, P.K. Role of substance P in hydrogen sulfide-induced pulmonary inflammation in mice. Am. J. Physiol. Cell. Mol. Physiol. 2006, 291, L896-L904. [CrossRef]

93. Sidhapuriwala, J.N.; Ng, S.W.; Bhatia, M. Effects of hydrogen sulfide on inflammation in caerulein-induced acute pancreatitis. J. Inflamm. 2009, 6, 35. [CrossRef]

94. Esechie, A.; Enkhbaatar, P.; Traber, D.L.; Jonkam, C.; Lange, M.; Hamahata, A.; Djukom, C.; Whorton, E.B.; Hawkins, H.K.; Traber, L.D. Beneficial effect of a hydrogen sulphide donor (sodium sulphide) in an ovine model of burn-and smoke-induced acute lung injury. Br. J. Pharmacol. 2009, 158, 1442-1453. [CrossRef] [PubMed]

95. Song, Z.J.; Ng, M.Y.; Lee, Z.-W.; Dai, W.; Hagen, T.; Moore, P.K.; Huang, D.; Deng, L.-W.; Tan, C.-H. Hydrogen sulfide donors in research and drug development. Med. Chem. Comm. 2014, 5, 557-570. [CrossRef]

96. Ahmad, A.; Szabo, C. Both the H $2 \mathrm{~S}$ biosynthesis inhibitor aminooxyacetic acid and the mitochondrially targeted H $2 \mathrm{~S}$ donor AP39 exert protective effects in a mouse model of burn injury. Pharmacol. Res. 2016, 113, 348-355. [CrossRef]

97. Faller, S.; Ryter, S.W.; Choi, A.M.K.; Loop, T.; Schmidt, R.; Hoetzel, A. Inhaled Hydrogen Sulfide Protects against Ventilatorinduced Lung Injury. Anesthesiology 2010, 113, 104-115. [CrossRef] [PubMed]

98. Francis, R.C.; Vaporidi, K.; Bloch, K.D.; Ichinose, F.; Zapol, W.M. Protective and detrimental effects of sodium sulfide and hydrogen sulfide in murine ventilator-induced lung injury. Anesthesiology 2011, 115, 1012-1021. [CrossRef] [PubMed]

99. Asher, I.; Pearce, N. Global burden of asthma among children. Int. J. Tuberc. Lung Dis. 2014, 18, 1269-1278. [CrossRef]

100. Derwall, M.; Francis, R.C.; Kida, K.; Bougaki, M.; Crimi, E.; Adrie, C.; Zapol, W.M.; Ichinose, F. Administration of hydrogen sulfide via extracorporeal membrane lung ventilation in sheep with partial cardiopulmonary bypass perfusion: A proof of concept study on metabolic and vasomotor effects. Crit. Care 2011, 15, R51. [CrossRef]

101. Perry, M.M.; Hui, C.; Whiteman, M.; Wood, M.E.; Adcock, I.; Kirkham, P.; Chung, K.F. Hydrogen Sulfide Inhibits Proliferation and Release of IL-8 from Human Airway Smooth Muscle Cells. Am. J. Respir. Cell Mol. Biol. 2011, 45, 746-752. [CrossRef]

102. Tian, M.; Wang, Y.; Lu, Y.-Q.; Yan, M.; Jiang, Y.-H.; Zhao, D.-Y. Correlation between serum $\mathrm{H}_{2} \mathrm{~S}$ and pulmonary function in children with bronchial asthma. Mol. Med. Rep. 2012, 6, 335-338. [CrossRef]

103. Zhang, P.; Li, F.; Wiegman, C.H.; Zhang, M.; Hong, Y.; Gong, J.; Chang, Y.; Zhang, J.; Adcock, I.; Chung, K.F.; et al. Inhibitory Effect of Hydrogen Sulfide on Ozone-Induced Airway Inflammation, Oxidative Stress, and Bronchial Hyperresponsiveness. Am. J. Respir. Cell Mol. Biol. 2015, 52, 129-137. [CrossRef]

104. Мa, Y.; Yan, Z.; Deng, X.; Guo, J.; Hu, J.; Yu, Y.; Jiao, F. Anticancer effect of exogenous hydrogen sulfide in cisplatin-resistant A549/DDP cells. Oncol. Rep. 2018, 39, 2969-2977. [CrossRef]

105. Bhatia, M. Role of Hydrogen Sulfide in the Pathology of Inflammation. Scientifica 2012, 2012, 1-12. [CrossRef]

106. Fiorucci, S.; Orlandi, S.; Mencarelli, A.; Caliendo, G.; Santagada, V.; Distrutti, E.; Santucci, L.; Cirino, G.; Wallace, J.L. Enhanced activity of a hydrogen sulphide-releasing derivative of mesalamine (ATB-429) in a mouse model of colitis. Br. J. Pharmacol. 2007, 150, 996-1002. [CrossRef] [PubMed]

107. Xu, D.-Q.; Gao, C.; Niu, W.; Li, Y.; Wang, Y.-X.; Gao, C.-J.; Ding, Q.; Yao, L.-N.; Chai, W.; Li, Z.-C. Sodium hydrosulfide alleviates lung inflammation and cell apoptosis following resuscitated hemorrhagic shock in rats. Acta Pharmacol. Sin. 2013, 34, 1515-1525. [CrossRef]

108. Bhatia, M. $\mathrm{H}_{2} \mathrm{~S}$ and Inflammation: An Overview. Handb. Exp. Pharmacol. 2015, 230, 165-180. [CrossRef]

109. Guo, F.; Yu, T.; Hong, J.; Fang, J. Emerging Roles of Hydrogen Sulfide in Inflammatory and Neoplastic Colonic Diseases. Front. Physiol. 2016, 7, 156. [CrossRef]

110. Saglam, K.; Alhan, E.; Turkyilmaz, S.; Vanizor, B.K.; Ercin, C. The anti-inflammatory effect of hydrogen sulphide on acute necrotizing pancreatitis in rats. Turk. J. Surg. 2017, 33, 158-163. [CrossRef]

111. Campos, D.; Ravagnani, F.G.; Gurgueira, S.A.; Vercesi, A.E.; Teixeira, S.A.; Costa, S.K.; Muscará, M.N.; Ferreira, H.H. Increased glutathione levels contribute to the beneficial effects of hydrogen sulfide and inducible nitric oxide inhibition in allergic lung inflammation. Int. Immunopharmacol. 2016, 39, 57-62. [CrossRef] [PubMed]

112. Aslami, H.; Pulskens, W.P.; Kuipers, M.T.; Bos, A.P.; Van Kuilenburg, A.B.P.; Wanders, R.J.A.; Roelofsen, J.; Roelofs, J.J.T.H.; Kerindongo, R.P.; Beurskens, C.J.P.; et al. Hydrogen Sulfide Donor NaHS Reduces Organ Injury in a Rat Model of Pneumococcal Pneumosepsis, Associated with Improved Bio-Energetic Status. PLoS ONE 2013, 8, e63497. [CrossRef] [PubMed]

113. Großhennig, S.; Ischebeck, T.; Gibhardt, J.; Busse, J.; Feussner, I.; Stülke, J. Hydrogen sulfide is a novel potential virulence factor of M ycoplasma pneumoniae: Characterization of the unusual cysteine desulfurase/desulfhydrase HapE. Mol. Microbiol. 2016, 100, 42-54. [CrossRef] [PubMed]

114. Oliver, E.; Ma, Y.; Escaffre, O.; Ivanciuc, T.; Komaravelli, N.; Kelley, J.P.; Coletta, C.; Szabo, C.; Rockx, B.; Garofalo, R.P.; et al. Role of Hydrogen Sulfide in Paramyxovirus Infections. J. Virol. 2015, 89, 5557-5568. [CrossRef] 
115. Cowley, E.S.; Kopf, S.H.; Lariviere, A.; Ziebis, W.; Newman, D.K. Pediatric Cystic Fibrosis Sputum Can Be Chemically Dynamic, Anoxic, and Extremely Reduced Due to Hydrogen Sulfide Formation. mBio 2015, 6, e00767-15. [CrossRef] [PubMed]

116. Gaddam, R.R.; Fraser, R.; Badiei, A.; Chambers, S.; Cogger, V.C.; Le Couteur, D.G.; Ishii, I.; Bhatia, M. Cystathionine-Gamma-Lyase Gene Deletion Protects Mice against Inflammation and Liver Sieve Injury following Polymicrobial Sepsis. PLoS ONE 2016, 11, e0160521. [CrossRef]

117. Zhang, H.; Zhi, L.; Moochhala, S.; Moore, P.K.; Bhatia, M. Hydrogen sulfide acts as an inflammatory mediator in cecal ligation and puncture-induced sepsis in mice by upregulating the production of cytokines and chemokines via NF-kB. Am. J. Physiol. Lung Cell Mol. Physiol. 2007, 292, L960-L971. [CrossRef] [PubMed]

118. El-Chemaly, S.; Levine, S.J.; Moss, J. Lymphatics in Lung Disease. Ann. N. Y. Acad. Sci. 2008, 1131, 195-202. [CrossRef] [PubMed]

119. Reed, H.O.; Wang, L.; Sonett, J.; Chen, M.; Yang, J.; Li, L.; Aradi, P.; Jakus, Z.; D'Armiento, J.M.; Hancock, W.W.; et al. Lymphatic impairment leads to pulmonary tertiary lymphoid organ formation and alveolar damage. J. Clin. Investig. 2019, 129, 2514-2526. [CrossRef] [PubMed]

120. Erb, A.; Althaus, M. Actions of Hydrogen Sulfide on Sodium Transport Processes across Native Distal Lung Epithelia (Xenopus laevis). PLoS ONE 2014, 9, e100971. [CrossRef] [PubMed]

121. Althaus, M.; Clauss, W.G.; Fronius, M. Amiloride-Sensitive Sodium Channels and Pulmonary Edema. Pulm. Med. 2010, 2011, 1-8. [CrossRef]

122. Egli, M.; Duplain, H.; Lepori, M.; Cook, S.; Nicod, P.; Hummler, E.; Sartori, C.; Scherrer, U. Defective respiratory amiloridesensitive sodium transport predisposes to pulmonary oedema and delays its resolution in mice. J. Physiol. 2004, 560, 857-865. [CrossRef]

123. Kubo, S.; Doe, I.; Kurokawa, Y.; Kawabata, A. Hydrogen sulfide causes relaxation in mouse bronchial smooth muscle. J. Pharmacol. Sci. 2007, 104, 392-396. [CrossRef]

124. Gharib-Naseri, M.K.; Saberi, S.; Mard, S.A.; Latifi, S.M. Bronchodilatory Effect of Hydrogen Sulfide in Rat. Iran. J. Basic Med. Sci 2012, 15, 907-915.

125. Zhang, Y.-L.; Chen, P.-X.; Guan, W.-J.; Guo, H.-M.; Qiu, Z.-E.; Xu, J.-W.; Luo, Y.-L.; Lan, C.-F.; Xu, J.-B.; Hao, Y.; et al. Increased intracellular $\mathrm{Cl}$ - concentration promotes ongoing inflammation in airway epithelium. Mucosal Immunol. 2018, 11, 1149-1157. [CrossRef] [PubMed]

126. Zhou, X.; An, G.; Chen, J. Inhibitory effects of hydrogen sulphide on pulmonary fibrosis in smoking rats via attenuation of oxidative stress and inflammation. J. Cell. Mol. Med. 2014, 18, 1098-1103. [CrossRef]

127. Song, K.; Li, Q.; Yin, X.-Y.; Lu, Y.; Liu, C.-F.; Hu, L.-F. Hydrogen Sulfide: A Therapeutic Candidate for Fibrotic Disease? Oxidative Med. Cell. Longev. 2015, 2015, 1-10. [CrossRef]

128. Zhou, X.; Cao, Y.; Ao, G.; Hu, L.; Liu, H.; Wu, J.; Wang, X.; Jin, M.; Zheng, S.; Zhen, X. CaMKK $\beta$-dependent activation of AMP-activated protein kinase is critical to suppressive effects of hydrogen sulfide on neuroinflammation. Antioxid. Redox Signal. 2014, 21, 1741-1758. [CrossRef]

129. Wang, Z.; Yin, X.; Gao, L.; Feng, S.; Song, K.; Li, L.; Lu, Y.; Shen, H. The protective effect of hydrogen sulfide on systemic sclerosis associated skin and lung fibrosis in mice model. SpringerPlus 2016, 5, 1084. [CrossRef] [PubMed]

130. Zhang, S.; Pan, C.; Zhou, F.; Yuan, Z.; Wang, H.; Cui, W.; Zhang, G. Hydrogen Sulfide as a Potential Therapeutic Target in Fibrosis. Oxidative Med. Cell. Longev. 2015, 2015, 1-12. [CrossRef] [PubMed]

131. Fleischmann, M.C.; Scherag, A.; Adhikari, N.K.J.; Hartog, C.S.; Tsaganos, T.; Schlattmann, P.; Angus, D.C.; Reinhart, K. Assessment of Global Incidence and Mortality of Hospital-treated Sepsis. Current Estimates and Limitations. Am. J. Respir. Crit. Care Med. 2016, 193, 259-272. [CrossRef]

132. Ang, S.-F.; Moochhala, S.M.; MacAry, P.A.; Bhatia, M. Hydrogen sulfide and neurogenic inflammation in polymicrobial sepsis: Involvement of substance P and ERK-NF-kB signaling. PLoS ONE 2011, 6, e24535. [CrossRef] [PubMed]

133. Zhang, H.; Hegde, A.; Ng, S.W.; Adhikari, S.; Moochhala, S.M.; Bhatia, M. Hydrogen sulfide up-regulates substance P in polymicrobial sepsis-associated lung injury. J. Immunol. 2007, 179, 4153-4160. [CrossRef] [PubMed]

134. Jiang, T.; Yang, W.; Zhang, H.; Song, Z.; Liu, T.; Lv, X. Hydrogen Sulfide Ameliorates Lung Ischemia-Reperfusion Injury Through SIRT1 Signaling Pathway in Type 2 Diabetic Rats. Front. Physiol. 2020, 11, 596. [CrossRef] [PubMed]

135. George, T.J.; Arnaoutakis, G.J.; Beaty, C.A.; Jandu, S.K.; Santhanam, L.; Berkowitz, D.E.; Shah, A.S. Inhaled hydrogen sulfide improves graft function in an experimental model of lung transplantation. J. Surg. Res. 2012, 178, 593-600. [CrossRef]

136. Wu, J.-X.; Wei, J.; You, X.; Chen, X.; Zhu, H.; Zhu, X.; Liu, Y.; Xu, M. Inhibition of hydrogen sulfide generation contributes to lung injury after experimental orthotopic lung transplantation. J. Surg. Res. 2013, 182, e25-e33. [CrossRef] [PubMed]

137. Wanamaker, B.; Cascino, T.; McLaughlin, V.; Oral, H.; Latchamsetty, R.; Siontis, K.C. Atrial Arrhythmias in Pulmonary Hypertension: Pathogenesis, Prognosis and Management. Arrhythmia Electrophysiol. Rev. 2018, 7, 43-48. [CrossRef]

138. Xiaohui, L.; Junbao, D.; Lin, S.; Jian, L.; Xiuying, T.; Jianguang, Q.; Bing, W.; Hongfang, J.; Chaoshu, T. Down-Regulation of Endogenous Hydrogen Sulfide Pathway in Pulmonary Hypertension and Pulmonary Vascular Structural Remodeling Induced by High Pulmonary Blood Flow in Rats. Circ. J. 2005, 69, 1418-1424. [CrossRef] [PubMed]

139. Wu, J.; Pan, W.; Wang, C.; Dong, H.; Xing, L.; Hou, J.; Fang, S.; Li, H.; Yang, F.; Yu, B. $\mathrm{H}_{2} \mathrm{~S}$ attenuates endoplasmic reticulum stress in hypoxia-induced pulmonary artery hypertension. Biosci. Rep. 2019, 39, BSR20190304. [CrossRef]

140. Wei, H.-L.; Zhang, C.-Y.; Jin, H.-F.; Tang, C.-S.; Du, J.-B. Hydrogen sulfide regulates lung tissue-oxidized glutathione and total antioxidant capacity in hypoxic pulmonary hypertensive rats. Acta Pharmacol. Sin. 2008, 29, 670-676. [CrossRef] 
141. Peng, Y.-J.; Zhang, X.; Gridina, A.; Chupikova, I.; McCormick, D.L.; Thomas, R.J.; Scammell, T.E.; Kim, G.; Vasavda, C.; Nanduri, J.; et al. Complementary roles of gasotransmitters $\mathrm{CO}$ and $\mathrm{H}_{2} \mathrm{~S}$ in sleep apnea. Proc. Natl. Acad. Sci. USA 2017, 114, 1413-1418. [CrossRef]

142. Yuan, G.; Peng, Y.-J.; Khan, S.A.; Nanduri, J.; Singh, A.; Vasavda, C.; Semenza, G.L.; Kumar, G.K.; Snyder, S.H.; Prabhakar, N.R. $\mathrm{H}_{2} \mathrm{~S}$ production by reactive oxygen species in the carotid body triggers hypertension in a rodent model of sleep apnea. Sci. Signal. 2016, 9, ra80. [CrossRef] [PubMed]

143. Claudet, I.; Marcoux, M.-O.; Karsenty, C.; Rittié, J.-L.; Honorat, R.; Lelong-Tissier, M. Intoxication accidentelle grave à l’hydrogène sulfuré: Un cas pédiatrique de survie. Ann. Françaises D'anesthésie Et De Réanimation 2012, 31, 255-258. [CrossRef] [PubMed]

144. Muzaffar, S.; Jeremy, J.Y.; Sparatore, A.; Del Soldato, P.; Angelini, G.D.; Shukla, N. H2 S-donating sildenafil (ACS6) inhibits superoxide formation and gp91phox expression in arterial endothelial cells: Role of protein kinases A and G. Br. J. Pharmacol. 2008, 155, 984-994. [CrossRef] [PubMed]

145. Lin, H.; Wang, X. The effects of gasotransmitters on bronchopulmonary dysplasia. Eur. J. Pharmacol. 2020, 873, 172983. [CrossRef] [PubMed]

146. Madurga, A.; Mižíková, I.; Ruiz-Camp, J.; Vadász, I.; Herold, S.; Mayer, K.; Fehrenbach, H.; Seeger, W.; Morty, R.E. Systemic hydrogen sulfide administration partially restores normal alveolarization in an experimental animal model of bronchopulmonary dysplasia. Am. J. Physiol. Cell. Mol. Physiol. 2014, 306, L684-L697. [CrossRef]

147. Calderone, V.; Martelli, A.; Testai, L.; Citi, V.; Breschi, M.C. Using hydrogen sulfide to design and develop drugs. Expert Opin. Drug Discov. 2015, 11, 163-175. [CrossRef]

148. Citi, V.; Piragine, E.; Testai, L.; Breschi, M.C.; Calderone, V.; Martelli, A. The Role of Hydrogen Sulfide and $\mathrm{H}_{2} \mathrm{~S}-\mathrm{donors}$ in Myocardial Protection against Ischemia/Reperfusion Injury. Curr. Med. Chem. 2018, 25, 4380-4401. [CrossRef]

149. Zhang, G.; Wang, P.; Yang, G.; Cao, Q.; Wang, R. The Inhibitory Role of Hydrogen Sulfide in Airway Hyperresponsiveness and Inflammation in a Mouse Model of Asthma. Am. J. Pathol. 2013, 182, 1188-1195. [CrossRef] [PubMed]

150. Rashid, S.; Heer, J.; Garle, M.; Alexander, S.; Roberts, R. Hydrogen sulphide-induced relaxation of porcine peripheral bronchioles. Br. J. Pharmacol. 2013, 168, 1902-1910. [CrossRef] [PubMed]

151. Castro-Piedras, I.; Perez-Zoghbi, J.F. Hydrogen sulphide inhibits Ca2+release through InsP3receptors and relaxes airway smooth muscle. J. Physiol. 2013, 591, 5999-6015. [CrossRef]

152. Huang, J.; Luo, Y.-L.; Hao, Y.; Zhang, Y.-L.; Chen, P.-X.; Xu, J.-W.; Chen, M.; Luo, Y.-F.; Zhong, N.-S.; Xu, J.; et al. Cellular mechanism underlying hydrogen sulfide induced mouse tracheal smooth muscle relaxation: Role of BKCa. Eur. J. Pharmacol. 2014, 741, 55-63. [CrossRef]

153. Hosoki, R.; Matsuki, N.; Kimura, H. The Possible Role of Hydrogen Sulfide as an Endogenous Smooth Muscle Relaxant in Synergy with Nitric Oxide. Biochem. Biophys. Res. Commun. 1997, 237, 527-531. [CrossRef]

154. Wang, Y.-F.; Mainali, P.; Tang, C.-S.; Shi, L.; Zhang, C.-Y.; Yan, H.; Liu, X.-Q.; Du, J.-B. Effects of nitric oxide and hydrogen sulfide on the relaxation of pulmonary arteries in rats. Chin. Med. J. 2008, 121, 420-423. [CrossRef] [PubMed]

155. Costantino, M.; Lampa, E.; Nappi, G. Effectiveness of sulphur spa therapy with politzer in the treatment of rhinogenic deafness. Acta Otorhinolaryngol. Ital. 2006, 26, 7-13.

156. Pouokam, E.; Althaus, M. Epithelial Electrolyte Transport Physiology and the Gasotransmitter Hydrogen Sulfide. Oxidative Med. Cell. Longev. 2016, 2016, 1-13. [CrossRef]

157. Faller, S.; Hausler, F.; Goeft, A.; Von Itter, M.-N.A.; Gyllenram, V.; Hoetzel, A.; Spassov, S.G. Hydrogen sulfide limits neutrophil transmigration, inflammation, and oxidative burst in lipopolysaccharide-induced acute lung injury. Sci. Rep. 2018, 8, 1-10. [CrossRef]

158. Zhang, D.; Wang, X.; Chen, S.; Chen, S.; Yu, W.; Liu, X.; Yang, G.; Tao, Y.; Tang, X.; Bu, D.; et al. Endogenous hydrogen sulfide sulfhydrates IKK $\beta$ at cysteine 179 to control pulmonary artery endothelial cell inflammation. Clin. Sci. 2019, 133, 2045-2059. [CrossRef] [PubMed]

159. Zanardo, R.C.O.; Brancaleone, V.; Distrutti, E.; Fiorucci, S.; Cirino, G.; Wallace, J.L. Hydrogen sulfide is an endogenous modulator of leukocyte-mediated inflammation. Faseb J. 2006, 20, 2118-2120. [CrossRef] [PubMed]

160. Brancaleone, V.; Mitidieri, E.; Flower, R.J.; Cirino, G.; Perretti, M. Annexin A1 Mediates Hydrogen Sulfide Properties in the Control of Inflammation. J. Pharmacol. Exp. Ther. 2014, 351, 96-104. [CrossRef] [PubMed]

161. Benavides, G.A.; Squadrito, G.L.; Mills, R.W.; Patel, H.D.; Isbell, T.S.; Patel, R.P.; Darley-Usmar, V.M.; Doeller, J.E.; Kraus, D.W. Hydrogen sulfide mediates the vasoactivity of garlic. Proc. Natl. Acad. Sci. USA 2007, 104, 17977-17982. [CrossRef]

162. Martelli, A.; Testai, L.; Citi, V.; Marino, A.; Pugliesi, I.; Barresi, E.; Nesi, G.; Rapposelli, S.; Taliani, S.; Da Settimo, F.; et al. Arylthioamides as $\mathrm{H}_{2} \mathrm{~S}$ Donors: L-Cysteine-Activated Releasing Properties and Vascular effects in vitro and in vivo. ACS Med. Chem. Lett. 2013, 4, 904-908. [CrossRef]

163. Liu, Y.; Li, A.; Feng, X.; Sun, X.; Zhu, X.; Zhao, Z. Pharmacological Investigation of the Anti-Inflammation and Anti-Oxidation Activities of Diallyl Disulfide in a Rat Emphysema Model Induced by Cigarette Smoke Extract. Nutrients 2018, 10, 79. [CrossRef]

164. Lucarini, E.; Micheli, L.; Trallori, E.; Citi, V.; Martelli, A.; Testai, L.; De Nicola, G.R.; Iori, R.; Calderone, V.; Ghelardini, C.; et al. Effect of glucoraphanin and sulforaphane against chemotherapy-induced neuropathic pain: Kv7 potassium channels modulation by H2 S release in vivo. Phytother. Res. 2018, 32, 2226-2234. [CrossRef] 
165. Citi, V.; Corvino, A.; Fiorino, F.; Frecentese, F.; Magli, E.; Perissutti, E.; Santagada, V.; Brogi, S.; Flori, L.; Gorica, E.; et al. Structureactivity relationships study of isothiocyanates for $\mathrm{H}_{2} \mathrm{~S}$ releasing properties: 3-Pyridyl-isothiocyanate as a new promising cardioprotective agent. J. Adv. Res. 2021, 27, 41-53. [CrossRef] [PubMed]

166. Citi, V.; Martelli, A.; Gorica, E.; Brogi, S.; Testai, L.; Calderone, V. Role of hydrogen sulfide in endothelial dysfunction: Pathophysiology and therapeutic approaches. J. Adv. Res. 2021, 27, 99-113. [CrossRef]

167. Citi, V.; Martelli, A.; Testai, L.; Marino, A.; Breschi, M.C.; Calderone, V. Hydrogen Sulfide Releasing Capacity of Natural Isothiocyanates: Is It a Reliable Explanation for the Multiple Biological Effects of Brassicaceae? Planta Med. 2014, 80, 610-613. [CrossRef]

168. Citi, V.; Piragine, E.; Pagnotta, E.; Ugolini, L.; Mannelli, L.D.C.; Testai, L.; Ghelardini, C.; Lazzeri, L.; Calderone, V.; Martelli, A. Anticancer properties of erucin, an $\mathrm{H}_{2} \mathrm{~S}$-releasing isothiocyanate, on human pancreatic adenocarcinoma cells (AsPC-1). Phytother. Res. 2019, 33, 845-855. [CrossRef]

169. Martelli, A.; Citi, V.; Testai, L.; Brogi, S.; Calderone, V. Organic Isothiocyanates as Hydrogen Sulfide Donors. Antioxid. Redox Signal. 2020, 32, 110-144. [CrossRef] [PubMed]

170. Martelli, A.; Piragine, E.; Citi, V.; Testai, L.; Pagnotta, E.; Ugolini, L.; Lazzeri, L.; Mannelli, L.D.C.; Manzo, O.L.; Bucci, M.; et al. Erucin exhibits vasorelaxing effects and antihypertensive activity by $\mathrm{H}_{2} \mathrm{~S}$-releasing properties. Br. J. Pharmacol. 2020, 177, 824-835. [CrossRef]

171. Sestito, S.; Pruccoli, L.; Runfola, M.; Citi, V.; Martelli, A.; Saccomanni, G.; Calderone, V.; Tarozzi, A.; Rapposelli, S. Design and synthesis of $\mathrm{H}_{2} \mathrm{~S}$-donor hybrids: A new treatment for Alzheimer's disease? Eur. J. Med. Chem. 2019, 184, 111745. [CrossRef]

172. Takayama, K.; Hirose, A.; Suda, I.; Miyazaki, A.; Oguchi, M.; Onotogi, M.; Fotopoulos, G. Comparison of the Anti-Inflammatory and Analgesic Effects in Rats of Diclofenac-Sodium, Felbinac and Indomethacin Patches. Int. J. Biomed. Sci. 2011, 7, $222-229$.

173. Jia, G.; Yu, S.; Sun, W.; Yang, J.; Wang, Y.; Qi, Y.; Chen, Y. Hydrogen Sulfide Attenuates Particulate Matter-Induced Emphysema and Airway Inflammation Through Nrf2-Dependent Manner. Front. Pharmacol. 2020, 11, 29. [CrossRef] [PubMed]

174. McCook, O.; Radermacher, P.; Volani, C.; Asfar, P.; Ignatius, A.; Kemmler, J.; Möller, P.; Szabó, C.; Whiteman, M.; Wood, M.E.; et al. $\mathrm{H}_{2} \mathrm{~S}$ during circulatory shock: Some unresolved questions. Nitric Oxide 2014, 41, 48-61. [CrossRef] [PubMed]

175. Nagy, P.; Pálinkás, Z.; Nagy, A.; Budai, B.; Tóth, I.; Vasas, A. Chemical aspects of hydrogen sulfide measurements in physiological samples. Biochim. Biophys. Acta 2014, 1840, 876-891. [CrossRef] [PubMed]

176. Wu, N.; Du, X.; Wang, D.; Hao, F. Myocardial and lung injuries induced by hydrogen sulfide and the effectiveness of oxygen therapy in rats. Clin. Toxicol. 2011, 49, 161-166. [CrossRef]

177. Olson, K.R.; DeLeon, E.R.; Gao, Y.; Hurley, K.; Sadauskas, V.; Batz, C.; Stoy, G.F. Thiosulfate: A readily accessible source of hydrogen sulfide in oxygen sensing. Am. J. Physiol. Regul. Integr. Comp. Physiol. 2013, 305, R592-R603. [CrossRef]

178. Szabo, C.; Papapetropoulos, A. International Union of Basic and Clinical Pharmacology. CII: Pharmacological Modulation of $\mathrm{H}_{2} \mathrm{~S}$ Levels: $\mathrm{H}_{2} \mathrm{~S}$ Donors and $\mathrm{H}_{2} \mathrm{~S}$ Biosynthesis Inhibitors. Pharmacol. Rev. 2017, 69, 497-564. [CrossRef] [PubMed]

179. Xu, S.; Yang, C.-T.; Meng, F.-H.; Pacheco, A.; Chen, L.; Xian, M. Ammonium tetrathiomolybdate as a water-soluble and slow-release hydrogen sulfide donor. Bioorganic Med. Chem. Lett. 2016, 26, 1585-1588. [CrossRef] [PubMed]

180. Dyson, A.; Dal-Pizzol, F.; Sabbatini, G.; Lach, A.B.; Galfo, F.; Cardoso, J.D.S.; Mendonça, B.P.; Hargreaves, I.; Pinto, B.B.; Bromage, D.I.; et al. Ammonium tetrathiomolybdate following ischemia/reperfusion injury: Chemistry, pharmacology, and impact of a new class of sulfide donor in preclinical injury models. PLoS Med. 2017, 14, e1002310. [CrossRef]

181. Donnarumma, E.; Ali, M.J.; Rushing, A.M.; Scarborough, A.L.; Bradley, J.M.; Organ, C.L.; Islam, K.N.; Polhemus, D.J.; Evangelista, S.; Cirino, G.; et al. Zofenopril Protects Against Myocardial Ischemia-Reperfusion Injury by Increasing Nitric Oxide and Hydrogen Sulfide Bioavailability. J. Am. Hear. Assoc. 2016, 5, 003531. [CrossRef]

182. Neuwelt, E.A.; Gilmer-Knight, K.; Lacy, C.; Nicholson, H.S.; Kraemer, D.F.; Doolittle, N.D.; Hornig, G.W.; Muldoon, L.L. Toxicity profile of delayed high dose sodium thiosulfate in children treated with carboplatin in conjunction with blood-brain-barrier disruption. Pediatr. Blood Cancer 2006, 47, 174-182.

183. Marutani, E.; Yamada, M.; Ida, T.; Tokuda, K.; Ikeda, K.; Kai, S.; Shirozu, K.; Hayashida, K.; Kosugi, S.; Hanaoka, K.; et al. Thiosulfate Mediates Cytoprotective Effects of Hydrogen Sulfide Against Neuronal Ischemia. J. Am. Heart Assoc. 2015,4 , e002125. [CrossRef]

184. Wallace, J.L.; Caliendo, G.; Santagada, V.; Cirino, G. Markedly reduced toxicity of a hydrogen sulphide-releasing derivative of naproxen (ATB-346). Br. J. Pharmacol. 2010, 159, 1236-1246. [CrossRef]

185. Ekundi-Valentim, E.; Mesquita, F.P.; Santos, K.T.; Paula, M.A.V.D.; Florenzano, J.; I Zanoni, C.; Rodrigues, L.; De Nucci, G.; A Teixeira, S.; Ferreira, H.H.; et al. A comparative study on the anti-inflammatory effects of single oral doses of naproxen and its hydrogen sulfide $\left(\mathrm{H}_{2} \mathrm{~S}\right)$-releasing derivative ATB-346 in rats with carrageenan-induced synovitis. Med. Gas. Res. $2013,3,24$. [CrossRef] [PubMed]

186. Wallace, J.L.; Nagy, P.; Feener, T.D.; Allain, T.; Ditrói, T.; Vaughan, D.J.; Muscara, M.N.; De Nucci, G.; Buret, A.G. A proof-ofconcept, Phase 2 clinical trial of the gastrointestinal safety of a hydrogen sulfide-releasing anti-inflammatory drug. Br. J. Pharmacol. 2020, 177, 769-777. [CrossRef]

187. Kashfi, K.; Chattopadhyay, M.; Kodela, R. NOSH-sulindac (AVT-18A) is a novel nitric oxide- and hydrogen sulfide-releasing hybrid that is gastrointestinal safe and has potent anti-inflammatory, analgesic, antipyretic, anti-platelet, and anti-cancer properties. Redox Biol. 2015, 6, 287-296. [CrossRef] 
188. Kodela, R.; Chattopadhyay, M.; Velázquez-Martínez, C.A.; Kashfi, K. NOSH-aspirin (NBS-1120), a novel nitric oxide- and hydrogen sulfide-releasing hybrid has enhanced chemo-preventive properties compared to aspirin, is gastrointestinal safe with all the classic therapeutic indications. Biochem. Pharmacol. 2015, 98, 564-572. [CrossRef] [PubMed]

189. Whiteman, M.; Li, L.; Rose, P.; Tan, C.-H.; Parkinson, D.B.; Moore, P.K. The Effect of Hydrogen Sulfide Donors on Lipopolysaccharide-Induced Formation of Inflammatory Mediators in Macrophages. Antioxid. Redox Signal. 2010, 12, 1147-1154. [CrossRef] [PubMed]

190. Li, L.; Salto-Tellez, M.; Tan, C.-H.; Whiteman, M.; Moore, P.K. GYY4137, a novel hydrogen sulfide-releasing molecule, protects against endotoxic shock in the rat. Free Radic. Biol. Med. 2009, 47, 103-113. [CrossRef] [PubMed] 